\title{
ARTICLES \\ THE FACTS ABOUT RING $V$. ARIZONA AND THE JURY'S ROLE IN CAPITAL SENTENCING
}

\author{
Sam Kamin* \\ Justin Marceau**
}

\section{INTRODUCTION: RING V. ARIZONA EIGHT YEARS LATER}

When it was decided in 2002, Ring $v$. Arizona ${ }^{1}$ appeared to be a watershed in the way capital sentences are handed out in the United States. Ring announced that the rule of Apprendi $v$. New Jersey ${ }^{2}$ applied to capital sentencing and required that any fact necessary to the imposition of the death penalty be proven to a jury and beyond a reasonable doubt. No longer could states remove capital decision making entirely from juries (as many states had done prior to Ring); rather, Ring appeared to signal that the jury has an important role to play in determining who lives and who dies.

Ring was initially seen, both by its proponents and its detractors, as a sea change in the way states could structure their capital decision making; it overturned several states' death penalty statutes and appeared to imperil many more. ${ }^{3}$ Yet eight years after the case was decided, it is not clear what, if anything, Ring demands of the states. As Justice Scalia made clear in his Ring concurrence, the case does not grant the right to have a jury determine a capital sentence. Rather, it

* Associate Professor, University of Denver Sturm College of Law; J.D., Ph.D University of California Berkeley; B.A. Amherst College.

** Assistant Professor, University of Denver Sturm College of Law; J.D. Harvard University; B.A. Boston College. The authors would like to thank the organizers and participants of the Southwestern Criminal Law Teachers' Workshop held at the University of Arizona as well as our colleagues at the University of Denver Sturm College of Law who attended and commented at our works in progress workshop. All errors and omissions are ours alone.

1536 U.S. 584 (2002).

2530 U.S. 466, 490 (2000) (holding that the Sixth Amendment right to a jury trial, as applied to the states via the Fourteenth Amendment, requires that "[o]ther than the fact of a prior conviction, any fact that increases the penalty for a crime beyond the prescribed statutory maximum must be submitted to a jury, and proved beyond a reasonable doubt").

3 See, e.g., Bryan A. Stevenson, The Ultimate Authority on the Ultimate Punishment: The Requisite Role of the Jury in Capital Sentencing, 54 ALA. L. REv. 1091, 1095 (2003) ("At the very least, Ring's express overruling of Walton calls into question-and justifies a revisiting of-a quarter-century of jurisprudence on the role of the jury in capital sentencing."). 
only precludes a judge from finding the facts that make the defendant eligible for a sentence of death; ${ }^{4}$ the ultimate sentence may still be imposed by a judge sitting without a jury. However, determining exactly what decision making constitutes fact finding and, therefore, which tasks must be carried out by the capital jury rather than a judge, remains a challenging task. ${ }^{5}$

In this Article, we investigate the impact of Ring by analyzing four typical capital statutes against both the language of the Ring opinion and the broader context of the Court's Sixth and Eighth Amendment jurisprudence. What we find is that in all but the most obvious cases, Ring's mandate is an extraordinarily weak one. Beyond these easiest cases, fact finding is a difficult concept to define ${ }^{6}$ and, as a result, state courts have consistently minimized Ring's impact on their capital systems. In the absence of firm guidance from the Supreme Court, the states have been left free to read Ring as they wish and have generally used this freedom to read Ring very narrowly.

To the extent that states are unwilling to hand complete control of capital cases over to juries (and, for various reasons many seem unwilling to do so $)^{7}$ Ring creates perverse incentives: juries can be removed from the equation simply by making capital decision making open-ended rather than fact-based, by making the decision to impose death a moral judgment rather than a legal conclusion. ${ }^{8}$

4 Ring, 536 U.S. at 612-13 (Scalia, J., concurring) ("What today's decision says is that the jury must find the existence of the fact that an aggravating factor existed. Those States that leave the ultimate life-or-death decision to the judge may continue to do so-by requiring a prior jury finding of aggravating factor in the sentencing phase or, more simply, by placing the aggravating-factor determination (where it logically belongs anyway) in the guilt phase.").

5 In other contexts, the Supreme Court has repeatedly emphasized that the task of establishing a "methodology for distinguishing questions of fact from questions of law has been, to say the least, elusive." Miller v. Fenton, 474 U.S. 104, 113 (1985) (citing Bose Corp. v. Consumers Union of U.S., Inc., 466 U.S. 485 (1984); Baumgartner v. United States, 322 U.S. 665, 671 (1944)); see also Williams v. Taylor, 529 U.S. 362, 408 (2000) (acknowledging that it is "difficult to distinguish a mixed question of law and fact from a question of fact").

6 See, e.g., Henry P. Monaghan, Constitutional Fact Review, 85 Colum. L. Rev. 229, 237 (1985) (" $[\mathrm{I}] \mathrm{t}$ seems misguided to assume, as many courts apparently do, that all law application judgments can be dissolved into either law declaration or fact identification.”).

7 See infra Part IV.

8 This reflects a peculiarly perverse incentive system because studies show that juries exercise much more ownership and care over capital sentencing when it is open-ended or unconstrained, as opposed to highly technical and legalized. See, e.g., Robert Weisberg, How Sentencing Commissions Turned out to Be a Good Idea, 12 BERKELEY J. CRIM. L. 179, 200-02 (2007). Because the strength of Ring's jury mandate is inversely proportional to the 
Such standardless decision making, while it currently passes constitutional muster under the Court's Eighth Amendment jurisprudence, ${ }^{9}$ remains constitutionally dubious. We demonstrate that the malleability of the capital sentencing process leaves the decision whether to impose death nearly unregulated by Ring and in need of a protective Eighth Amendment overlay. ${ }^{10}$ Stated another way, the role of the jury in capital sentencing is best realized not through the Sixth Amendment, but through the Eighth Amendment.

By examining the capital sentencing systems in four of the nation's most active death penalty states-Florida, Texas, California, and Georgia-we argue that the Sixth Amendment jury right, though of great importance in the non-capital context, ${ }^{11}$ tends to generate more confusion than protection in capital sentencing. Nonetheless, the possibility of a meaningful jury right in the capital sentencing context need not be abandoned entirely. In view of the shortcomings of the Sixth Amendment in this realm and in light of the retributive purpose underlying modern capital punishment, ${ }^{12}$ the wisdom of Jus-

amount of jury discretion, the jury right has the least force when it would be most effective.

9 See Zant v. Stephens, 462 U.S. 862, 875-76 n.13 (1983) (stating that the Court's decision in Jurek $v$. Texas makes clear that "specific standards for balancing aggravating against mitigating circumstances are not constitutionally required").

10 Of course, the role of the Eighth Amendment as a procedural stop-gap in capital sentencing issues is not a novel proposition. For the last forty years, the Court has recognized the role of the "cruel and unusual punishment clause" as providing a unique or additional protective procedural gloss to death penalty adjudications. See, e.g., id. at 884-85 (noting that "because there is a qualitative difference between death and any other permissible form of punishment, 'there is a corresponding difference in the need for reliability in the determination that death is the appropriate punishment in a specific case" (quoting Woodson v. North Carolina, 428 U.S. 280, 305 (1976) (plurality opinion))).

11 See, e.g., R. Craig Green, Apprendi's Limits, 39 U. RICH. L. REV. 1155, 1157 (2005) (describing Apprendi as the "landmark in modern sentencing law"); Joseph L. Hoffman, Apprendi v. New Jersey: Back to the Future?, 38 AM. CRIM. L. REv. 255, 255 (2001) (noting the importance of Apprendi in reigniting the debate from the 1970s and 1980s regarding the extent to which a "legislature, consistent with constitutional requirements, [can] shift the burden of persuasion in a criminal case" by simply redefining an element as a defense).

12 We believe that the Court's capital sentencing jurisprudence rests on a strongly, if not exclusively, retributive rationale. See Russell Dean Covey, Exorcising Wechsler's Ghost: The Influence of the Model Penal Code on Death Penalty Sentencing Jurisprudence, 31 Hastings CONST. L.Q. 189, 226 (2004) ("[S] everal Justices have expressly acknowledged that retribution is the only supportable basis for the death penalty."); $c f$. Baze v. Rees, 533 U.S. 35, 90 (2008) (Scalia, J., concurring) (noting that even if capital punishment served no deterrent purpose, "the death penalty would yet be constitutional . . . if it served the appropriate purpose of retribution"). Efforts to prove a statistically meaningful deterrent have been inconclusive, and if there is any ambiguity as to the purposes of sentencing, there is good reason to default in favor of jury sentencing. See Jenia Iontcheva, Jury Sentencing as Democratic Practice, 89 VA. L. REV. 311, 313 (2003) ("In the absence of wide consensus on sentencing goals, it is best to leave the sentencing decision with a deliberative democratic 
tices Stevens ${ }^{13}$ and Breyer ${ }^{14}$ in locating a capital jury right in the Eighth Amendment has been dramatically under-appreciated. Under their view of the Eighth Amendment, the role of the jury is crucial in capital sentencing not because of the jury's fact-finding prowess, but because the jury plays an indispensable role in expressing the conscience of the community. ${ }^{15}$ Recognizing an Eighth Amendment jury right is consistent with the Court's general approach to capital sentencing and better effectuates the jury-right promise of the Sixth Amendment than does the Sixth Amendment itself.

Part II of this Article provides an overview of the relevant constraints on capital sentencing imposed by the Sixth and Eighth Amendments. Part III applies these limits to four key death penalty jurisdictions and reveals the failure of Ring's promised jury right. In Part IV we conclude that the Eighth Amendment-rather than the Sixth-dictates that the uniquely democratic and retributive process of deciding who lives and who dies ought to be carried out not by a judge but by a jury.

\section{The Constitutional Regulation of the DeAth Penalty}

Capital punishment in the United States is regulated by two discrete but related Constitutional provisions: the Eighth Amendment's

institution-the jury."); id. at 328 (quoting the Federal Sentencing Commission's admitted inability to settle on a goal for punishment: "Such a choice would be profoundly difficult. The relevant literature is vast, the arguments deep, and each point of view has much to be said in its favor" (quoting Federal Sentencing Guidelines Manual, ch. 1, pt. A, introductory $\mathrm{cmt}$. (1990))).

13 See Harris v. Alabama, 513 U.S. 504, 526 (1995) (Stevens, J., dissenting) ("To permit the State to execute a woman in spite of the community's considered judgment that she should not die is to sever the death penalty from its only legitimate mooring."); Spaziano v. Florida, 468 U.S. 447, 490 (1984) (Stevens, J., concurring in part and dissenting in part) (explaining that because the state did not persuade a jury of the petitioner's peers "that death is an appropriate punishment for his offense[,]" the state had "authorized the imposition of disproportionate punishment in violation of the Eighth and Fourteenth Amendments").

14 Schriro v. Summerlin, 542 U.S. 348, 360 (2004) (Breyer, J., dissenting) ("I believe the Eighth Amendment demands the use of a jury in capital sentencing because a death sentence must reflect a community-based judgment that the sentence constitutes proper retribution.”); Ring v. Arizona, 536 U.S. 584, 614 (2002) (Breyer, J., concurring) ("I believe that jury sentencing in capital cases is mandated by the Eight Amendment.").

15 Ring, 536 U.S. at 615-16 ("In respect to retribution, jurors possess an important comparative advantage over judges.... [T] he jury remains uniquely capable of determining whether, given the community's views, capital punishment is appropriate in the particular case at hand."); see also Iontcheva, supra note 12, at 323 (tracing the history of the jury right and recounting the notion that it embodies "the ideal of a decentralized democracy" insofar as juries are the "vehicle through which community concerns could be made to bear on important political decisions"). 
prohibition on cruel and unusual punishment and the Sixth Amendment's jury trial guarantee. As this section makes clear, these two provisions exert competing pressures on states seeking to implement capital sentencing systems.

\section{A. Capital Punishment Post-Gregg: The Eighth Amendment Framework}

In 1972 the U.S. Supreme Court held in Furman v. Georgia ${ }^{16}$ that the death penalty, as it was then being carried out across the country, ${ }^{17}$ was wanton and arbitrary, thereby violating the Eighth and Fourteenth Amendments' prohibition on cruel and unusual punishment. ${ }^{18}$ Each of the Court's nine Justices wrote an opinion in Furman, making the decision long on pages but short on discernible rationales. ${ }^{19}$ Two of the Justices asserted that the death penalty is never constitutional and four found no constitutional fault with the Georgia statute directly at issue in the case. Thus, the import of the decision derives primarily from the opinions of the three Justices, Potter Stewart, Byron White and William O. Douglas, who did not state categorical objections to the death penalty, but rather found fault with the specifics of the Georgia statute. ${ }^{20}$

These three Justices focused on the broad discretion permitted to capital sentencers by the Georgia statute. ${ }^{21}$ Justice Stewart stated that

16408 U.S. 238 (1972).

17 Commentators have observed that "Furman had the effect of invalidating capital statutes passed by thirty-nine states, the District of Columbia, and the federal government." Carol S. Steiker \& Jordan M. Steiker, Sober Second Thoughts: Reflections on Two Decades of Constitutional Regulation of Capital Punishment, 109 HARV. L. REv. 355, 362 (1995); see also id. at 362 n.22 (noting that only Rhode Island's automatic, non-discretionary death penalty survived after Furman).

18 Furman, 408 U.S. at 239-40 (1972). Identifying the sentencing systems under review as arbitrarily assigning death, Justice Stewart memorably wrote, "These death sentences are cruel and unusual in the same way that being struck by lightening is cruel and unusual." $I d$. at 309 (Stewart, J., concurring).

19 Because the opinion of the Court was per curiam, the nine justices in Furman actually managed to produce ten separate opinions. See id. at 240; see also Steiker \& Steiker, supra note 17, at 362 (identifying Furman as the "longest decision ever to appear in the U.S. Reports").

20 See Pulley v. Harris, 465 U.S. 37, 44 (1984) (summarizing these three justices' rationales underlying their separate opinions in Furman); see also James S. Liebman, Slow Dancing with Death: The Supreme Court and Capital Punishment, 1963-2006, 107 COLUM. L. REv. 1, 8 (2007) (noting that Justices Douglas, Stewart, and White "controlled the outcome" of Furman).

21 See Furman, 408 U.S. at 253 (Douglas, J., concurring) ("Under these laws no standards govern the selection of the penalty. People live or die, dependent on the whim of one man or of 12."); id. at 309-10 (Stewart, J., concurring) (“[T] he petitioners are among a capriciously selected random handful upon whom the sentence of death has in fact been 
death sentences imposed under the statute were "cruel and unusual in the same way that being struck by lightning [was] cruel and unusual," ${ }^{22}$ the statute provides no guidance to the jury regarding how to determine a defendant's sentence and thus results in random, unpredictable, unprincipled death sentences. The other Justices in this group were concerned by the possibility of racial discrimination that broad discretion permitted and by the relatively small number of death sentences actually imposed compared to the much larger number of murders occurring in Georgia. ${ }^{23}$ For these Justices, a constitutional death penalty statute would require more rigorous, defined, and fixed criteria for determining those cases for which death was the appropriate punishment.

The states were sent back to the drawing board by Furman, forced to parse the opinions of Justices Stewart, White, and Douglas in order to determine what the Eighth Amendment required of them. But it was not long before a majority of the Court was satisfied that the problems of arbitrariness found repugnant to the Eighth Amendment in Furman had been remedied-Furman represents not the end, but the beginning, of the Supreme Court's regulation of state capital sentencing regimes. Less than four years after Furman had been handed down, the Court, in Gregg v. Georgia, upheld the new statute the Georgia legislature had passed in response to Furman. ${ }^{24}$ Although no definitive capital sentencing algorithm was mandated by the Court, the decision in Gregg, combined with separate opinions upholding the capital systems in Florida ${ }^{25}$ and Texas ${ }^{26}$ and rejecting the capital system of Louisiana, ${ }^{27}$ provided a set of guideposts for the states. Read together, these decisions sketch a rough outline of the type of procedures that would, for Eighth Amendment purposes, suf-

imposed."); $i d$. at 314 (White, J., concurring) (stating that the legislature delegated sentencing authority to juries and judges who exercised independent discretion).

22 Id. at 309 (Stewart, J., concurring).

$23 I d$. at 311 (White, J., concurring) ("[J]udges and juries have ordered the death penalty with such infrequency that the odds are now very much against imposition and execution of the penalty with respect to any convicted murderer or rapist."). Justice Douglas' concurring opinion focused on racial disparities in capital sentencing. Id. at 253-57 (Douglas, J., concurring).

24 Gregg v. Georgia, 428 U.S. 153, 207 (1976). Only the two absolutists, Brennan and Marshall, dissented. Id. at 227 (Brennan, J., dissenting); id. at 230 (Marshall, J., dissenting).

25 Proffitt v. Florida, 428 U.S. 242 (1976).

26 Jurek v. Texas, 428 U.S. 262 (1976).

27 Roberts v. Lousiana, 428 U.S. 325 (1976). 
ficiently guide the sentencer's discretion in assessing whether a defendant should live or die. ${ }^{28}$

On the same day that the Court expressly approved Georgia's revised capital sentencing system, however, the Court declared North Carolina's capital system unconstitutional in Woodson v. North Caroli$n a .^{29}$ The relevant North Carolina statute mandated capital punishment for all first degree murderers, and the Court held that this automatic death penalty statute was unconstitutional insofar as it denied the defendant the opportunity to have his individual characteristics considered by the sentencer. The Court explained, "North Carolina's mandatory death penalty statute for first-degree murder departs markedly from contemporary standards respecting the imposition of the punishment of death and thus cannot be applied consistently with the Eighth and Fourteenth Amendments' requirement that the State's power to punish 'be exercised within the limits of civilized standards. ${ }^{\prime 30}$

By the end of 1976, the Court had, through cases like Gregg and Woodson, essentially mandated that capital sentencing include two layers of narrowing: the class of eligible persons must be narrowed to the most severe murderers, ${ }^{31}$ and there must be a further narrowing such that only the most culpable of those individuals is sentenced to death. $^{32}$ States seeking to impose the death penalty must navigate be-

28 The procedures adopted to resolve the constitutional concerns raised in Furman, for the most part, track the Model Penal Code's capital sentencing provisions. Covey, supra note 12 , at 206-24.

29 Woodson v. North Carolina, 428 U.S. 280, 305 (1976) (plurality opinion).

$30 I d$. at 301 (quoting Trop v. Dulles, 356 U.S. 86, 100 (1958)). It is notable that the Court imported the evolving standards of decency framework for proportionality review under the Eighth Amendment into the realm of pure proceduralism. The Woodson rule addresses only the adequacy of the capital sentencing proceedings, and yet the Court expressly invokes "contemporary standards" as a gauge for the constitutionality of the procedure in question. Id.

31 See, e.g., G. Ben Cohen et al., A Cold Day in Apprendi-Land: Oregon v. Ice Brings Unknown Forecast for Apprendi's Continued Vitality in the Capital Sentencing Context, 3 HARV. L. \& POL'Y REV. ONLINE, at 6 (2009), http://www.hlpronline.com/Smith_HLPR_042409.pdf (describing narrowing as the process of filtering out all but "the most severe murders committed by the most culpable murderers").

32 Woodson, 428 U.S. at 304 (mandating individualized consideration before sentencing defendants in capital cases); see Gregg v. Georgia, 428 U.S. 153, 183 (1976) (stating that when considering sentencing a person to death, "the sanction imposed cannot be so totally without penological justification that it results in the gratuitous infliction of suffering"). Justice Scalia has observed that the individuation requirements of Woodson and the eligibility requirements of Gregg serve the same narrowing function-these two rules define a unitary determination: "Does this defendant deserve death for this crime?" Walton v. Arizona, 497 U.S. 639, 666 (1990) (Scalia, J., concurring) (emphasis added), overruled in part by Ring v. Arizona, 536 U.S. 584 (2002). 
tween two Eighth Amendment requirements. They cannot, under Furman, leave the sentencer the unfettered discretion whether to impose the death penalty or not, and they cannot, under Woodson, require that the death penalty be imposed under certain circumstances. The task of complying with the dual procedural requirements of the Eighth Amendment has resulted in an ongoing dialogue between the states and the Supreme Court regarding the propriety of various sentencing systems.

For his part, Justice Scalia has declared the task of complying with these twin goals to be impossible. ${ }^{34}$ Forced to choose between what he describes as contradictory commands to the states-make the death penalty difficult to impose and easy not to impose-Justice Scalia decided that he could follow only one. Reviewing the history of the two lines of cases, he could find constitutional support only for the Furman line and announced that he would no longer follow the rule created in Woodson and elaborated in Lockett v. Ohio: ${ }^{35}$

[Our] jurisprudence contain [s] the contradictory commands that discretion to impose the death penalty must be limited but discretion not to impose the death penalty must be virtually unconstrained.... I would not know how to apply [Woodson]-or, more precisely, how to apply both [Woodson] and Furman-if I wanted to. I cannot continue to say, in case after case, what degree of "narrowing" is sufficient to achieve the constitutional objective enunciated in Furman when I know that that objective is in any case impossible of achievement because of Woodson-Lockett. And I cannot continue to say, in case after case, what sort of restraints upon sentencer discretion are unconstitutional under Woodson-Lockett when I know that the Constitution positively favors constraints under Furman. Stare decisis cannot command the impossible. Since I cannot possibly be

33 Since 1976, the Court has been "involved in the ongoing business of determining which state schemes could pass constitutional muster," a process that has been described by some commentators as the Supreme Court's "regulatory role" in the field of capital punishment. Steiker \& Steiker, supra note 17, at 363.

34 Notably, Justice Scalia's pronouncement that he will now only apply one of the Eighth Amendment's two procedural requirements arose in a case that represents the Court's last decision affirming the principle that the Sixth Amendment does not require jury involvement in any stage of capital sentencing. Walton, 497 U.S. at 656-57 (Scalia, J., concurring). Not long after Walton was decided, the Court revisited the Sixth Amendment issue and reversed itself. See Ring v. Arizona, 536 U.S. 584, 589 (2002). Justice Scalia, however, has not revised his position as to the Eighth Amendment protections during sentencing. Id. at 610 (Scalia, J., concurring).

35 Walton, 497 U.S. at 673 (Scalia, J., concurring). In Lockett, the Court elaborated on the protections announced in Woodson. See Lockett v. Ohio, 438 U.S. 586, 605 (1978) (plurality opinion). 
guided by what seem to me incompatible principles, I must reject the one that is plainly in error.

For Scalia, the two sets of requirements-that sentencing discretion be suitably narrowed through rules and that all available evidence relevant to mitigation be admitted for consideration by the sentencerwere simply irreconcilable. ${ }^{37}$

In short, the Eight Amendment is sufficiently complicated on its own to make determining the constitutionality of any state's capital sentencing provision unclear. There is substantial disagreement about the role of Woodson's mandate that individual characteristics of the accused-mitigation-be considered as part of the capital sentencing proceeding and disagreement over what it means for a state to meaningfully narrow the pool of murderers to those who are ultimately eligible for death. These difficulties are exponentially compounded, however, by the fact that capital sentencing proceedings are also regulated by the Sixth Amendment jury right. Although the Court has squarely addressed, in Ring, the relationship between Furman's Eighth Amendment requirements and those requirements of the Sixth Amendment, it has not yet untangled the relationship between Woodson's additional requirements and the Sixth Amendment. ${ }^{38}$

36 Walton, 497 U.S. at 668, 673 (Scalia, J., concurring). For a critique of this view, see Scott E. Sundby, The Lockett Paradox: Reconciling Guided Discretion and Unguided Mitigation in Capital Sentencing, 38 UCLA L. REV. 1147, 1206 (1991) ("[W] hile the cases necessitate different approaches to sentencer discretion, Furman narrowing it and Lockett expanding it, they share the goal of identifying which defendants are within the state's power to execute under the $[\mathrm{E}]$ ighth $[\mathrm{A}]$ mendment.").

37 Given Scalia's generally robust notion of the Sixth Amendment jury right, perhaps his explicit rejection of the need for broad individualizing or mitigation review, as a matter of Eighth Amendment doctrine, has tainted his view as to whether such review warrants the Sixth Amendment jury protections. Given that he does not recognize a right to have one's sentence individualized under Woodson, it is not terribly surprising that he has groused that the jury right does not attach to this right. See Ring, 536 U.S. at 612 (Scalia, J., concurring) (“[T] he unfortunate fact is that today's judgment has nothing to do with jury sentencing. What today's decision says is that the jury must find the existence of the fact that an aggravating factor existed."). On the other hand, given that Scalia has recognized that aggravators and mitigators are doing the same constitutional work-narrowing the class of death-eligible defendants-his differing treatment of the two requirements for purposes of the jury right is incongruous.

38 At least for now, it seems clear that Justice Scalia has not prevailed in his quest to deconstitutionalize the Woodson rule. In recent years, the Court has repeatedly applied the requirement of broad, nearly unlimited admissibility principles regarding mitigation evidence in capital sentencing proceedings. See, e.g., Abdul-Kabir v. Quarterman, 550 U.S. 233, 263-64 (2007) (reiterating that the Court has long held that before imposing a death sentence, the jury "must be allowed to consider a defendant's moral culpability and decide whether death is an appropriate punishment for that individual in light of his personal history and characteristics and the circumstances of the offense"). 


\section{B. Capital Punishment and the Sixth Amendment}

\section{The Tension Builds: Developing a Coherent Sixth Amendment Theory for Capital Sentencing}

In Jones $v$. United States, ${ }^{39}$ the Supreme Court was asked to determine whether a provision of the federal carjacking statute, 18 U.S.C. $\S 2119(2)$, dealing with serious bodily injury was an element of the offense or merely a sentencing factor. ${ }^{40}$ Under this provision, a successful demonstration that the defendant had caused serious bodily injury during the course of his crime raised the potential punishment for carjacking from fifteen years to twenty-five years in prison. The Court reasoned-citing the due process cases In Re Winship ${ }^{41}$ and Patterson v. New York ${ }^{42}$ - that the government must allege all the elements of an offense in the charging document ${ }^{43}$ and must prove them to a

39 Jones v. United States, 526 U.S. 227 (1999). The relationship between sentencing factors and the Sixth Amendment jury right was first raised in a dissenting opinion by Justice Scalia one year before Jones. See Monge v. California, 524 U.S. 721, 738 (1998) (Scalia, J., dissenting) ("The fundamental distinction between facts that are elements of a criminal offense, and facts that go only to the sentence provides the foundation for our entire double jeopardy jurisprudence.... The same distinction also delimits the boundaries of other important constitutional rights, like the Sixth Amendment right to trial by jury .....").

The section read, in its entirety, as follows:

Whoever, with the intent to cause death or serious bodily harm takes a motor vehicle that has been transported, shipped, or received in interstate or foreign commerce from the person or presence of another by force and violence or by intimidation, or attempts to do so, shall-

(1) be fined under this title or imprisoned not more than 15 years, or both,

(2) if serious bodily injury ... results, be fined under this title or imprisoned not more than 25 years, or both, and

(3) if death results, be fined under this title or imprisoned for any number of years up to life, or both, or sentenced to death.

18 U.S.C. $\$ 2119$ (2006)

397 U.S. 358 (1970).

432 U.S. 197 (1977).

Although beyond the scope of this Article, the Fifth Amendment grand jury right, which produces the relevant charging document discussed in Jones, serves as yet another constitutional protection that is implicated by the Eighth Amendment's rules governing capital sentencing. Capital sentencing implicates at least four distinct constitutional provisions: (1) the Eighth Amendment requirements of Furman and Woodson; (2) the Sixth Amendment right to have a jury make findings of fact that increase one's maximum sentencing range; (3) the Fourteenth Amendment's requirement that elements be found by a jury beyond a reasonable doubt; and (4) the Fifth Amendment requirement that all elements be submitted to a grand jury. Of these four, only the grand jury right to an indictment as to all elements has not been incorporated so as to apply to the states. See United States v. Allen 406 F.3d 940, 943 (8th Cir. 2005) (en banc) ("The indictment must include at least one statutory aggravating factor to satisfy the Fifth Amendment because that is what is required to elevate the available statutory maximum sentence from life imprisonment to death. In turn, at least one of the statutory aggravating factors found by the petit jury in 
jury beyond a reasonable doubt. Mere sentencing provisions, by contrast, need generally be proven only to a judge and only by a preponderance of the evidence. ${ }^{44}$

Reviewing the carjacking provisions at issue in Jones, the Court concluded that serious constitutional questions would be raised by accepting the government's reading of the statute as specifying one offense with several sentencing factors. Were the allegation of serious bodily injury viewed merely as a sentencing factor, the Court reasoned, the jury's role in the adjudication of a criminal defendant would be greatly eroded:

The terms of the carjacking statute illustrate very well what is at stake. If serious bodily injury were merely a sentencing factor under $\S 2119(2)$ (increasing the authorized penalty by two thirds, to 25 years), then death would presumably be nothing more than a sentencing factor under subsection (3) (increasing the penalty range to life). If a potential penalty might rise from 15 years to life on a nonjury determination, the jury's role would correspondingly shrink from the significance usually carried by determinations of guilt to the relative importance of low-level gatekeeping: in some cases, a jury finding of fact necessary for a maximum 15 -year sentence would merely open the door to a judicial finding sufficient for life imprisonment. It is therefore no trivial question to ask whether recognizing an unlimited legislative power to authorize determinations setting ultimate sentencing limits without a jury would invite erosion of the jury's function to a point against which a line must necessarily be drawn.

To avoid these serious constitutional concerns, the Court concluded that the statute was more accurately read as containing three separate offenses ${ }^{46}$ — carjacking, carjacking with serious bodily harm resulting, and carjacking with death resulting-rather than one. Because the government had not alleged in the indictment ${ }^{47}$ or proven

imposing the death sentence must have been one of the statutory aggravating factors charged by the grand jury in the indictment.").

44 The Supreme Court recently reiterated this theme in United States v. O'Brien, 130 S. Ct. 2169, 2175 (2010) (explaining that "subject to" the Sixth Amendment requirements, the question of whether a fact is an element or a sentencing factor is "a question for Congress. When Congress is not explicit ... courts look to the provisions and the framework of the statute to determine whether a fact is an element or a sentencing factor").

45 Jones, 526 U.S. 227, 243-44 (1999).

$46 \quad I d$. at 251-52 ("Any doubt on the issue of statutory construction is hence to be resolved in favor of avoiding those questions. This is done by construing $§ 2119$ as establishing three separate offenses by the specification of distinct elements, each of which must be charged by indictment, proven beyond a reasonable doubt, and submitted to a jury for its verdict." (footnotes omitted)).

47 Cf. Jane Eggers, Note, McKaney v. Foreman: An Odd Departure from the Apprendi Line, 48 ARIZ. L. REV. 403, 411-12 (2006) (explaining the implications of the Supreme Court's Sixth Amendment cases discussing the indictment rule on states, which are not obligated to charge by indictment). 
beyond a reasonable doubt to a jury the fact that Jones had caused serious bodily injury in the commission of a carjacking, his maximum sentence was properly determined by what was in fact proven to the jury, namely a violation of the baseline offense of carjacking. ${ }^{48}$

In coming to the conclusion that the allegation of serious bodily injury was an element of the offense and not a mere sentencing factor, the Court was forced to distinguish three capital sentencing cases-Spaziano v. Florida, ${ }^{49}$ Hildwin v. Florida ${ }^{50}$ and Walton v. Arizona ${ }^{51}-$ which had all upheld the judge's traditional role as a fact finder in sentencing. Spaziano and Hildwin had both challenged Florida's death penalty scheme that allows a judge, as the ultimate sentencer under Florida law, to disregard a jury's recommendation of a life sentence and impose the death penalty. In Spaziano, the Court ruled that capital sentencing, like non-capital sentencing, is merely the process of choosing one alternative sentence over another, a task that has traditionally been one for the judge and not the jury. ${ }^{52}$ In the Court's brief, per curiam decision in Hildwin, it rejected the idea that the findings that lead to death must be made by a jury; the finding of such sentencing factors, the Court reasoned, is a task traditionally left to the judge and not the jury. ${ }^{53}$ Finally, in Walton, the Court rejected the petitioner's assertion that the findings that would make him death-eligible under Arizona law must be made by a jury; relying in part on Hildwin and Spaziano, the Supreme Court once again asserted that neither the Sixth Amendment nor the history of criminal sentencing in the United States mandate a role for the jury in the fact finding that leads to an increased sentence. ${ }^{54}$

48 Jones, 526 U.S. at 253 (Scalia, J., concurring) (noting that the result in Jones is governed by his "considered view" of the Sixth Amendment as announced in his Monge v. California dissent).

49468 U.S. 447 (1984).

50490 U.S. $638(1989)$.

51497 U.S. 639 (1990).

52 Spaziano, 468 U.S. at 458 ("Petitioner does not urge that capital sentencing is so much like a trial on guilt or innocence that it is controlled by the Court's decision in Duncan $v$. Lousiana." (citing Duncan v. Louisiana, 391 U.S. 145 (1968))).

53 Hildwin, 490 U.S. at 640-41 ("Like the visible possession of a firearm in McMillan, the existence of an aggravating factor here is not an element of the offense but instead is 'a sentencing factor that comes into play only after the defendant has been found guilty.' Accordingly, the Sixth Amendment does not require that the specific findings authorizing the imposition of the sentence of death be made by the jury." (quoting McMillan v. Pennsylvania, 477 U.S. 79, 86 (1986)) (citations omitted)). Notably, in McMillan v. Pennsylvania, the Court was not addressing a factual finding that increased the statutory maximum sentence. See McMillan v. Pennsylvania, 477 U.S. 79, 80-83 (1986).

54 See Walton, 497 U.S. at 647 ("Contrary to Walton's assertion ... '[a]ny argument that the Constitution requires that a jury impose the sentence of death or make the findings pre- 
The Court's attempt to distinguish these three capital cases from its Jones holding is, at least in retrospect, difficult to comprehend. If there is no constitutional infirmity in allowing a judge rather than a jury to find the facts that lead to death, why does allowing a judge to find that serious bodily harm resulted from a carjacking raise serious constitutional questions? If the Jones Court were so concerned that a defendant might be sentenced to life without specific jury findings, why did it seem willing to allow a defendant to be sentenced to death based upon the findings of a trial judge sitting without a jury?

Perhaps the answer lies in the Court's concern that the carjacking statute, as read by the government in Jones, would allow the jury only a gate-keeping function; a jury verdict would merely make the defendant guilty of a felony, but the ultimate seriousness of that felony would depend entirely on a judge's determination of additional facts not heard-or perhaps even rejected-by the jury. By contrast, in Florida, the jury determines whether or not the defendant is guilty of capital murder and the judge's fact finding and conclusion as to the ultimate punishment is limited to the narrow, but important, choice between life and death. ${ }^{55}$

Notwithstanding the obvious tension between the holding in Jones and the Court's extensive capital sentencing jurisprudence, the Supreme Court famously reaffirmed and generalized the holding of Jones in Apprendi, ${ }^{56}$ holding that the Constitutional concerns that the Court raised in Jones were in fact quite substantial..$^{57}$ Apprendi involved a hate crime allegation that doubled the maximum permissible prison term for the weapons violation to which the defendant had pleaded guilty. A judge sitting without a jury found the allegation of racial animus to be true to a preponderance of the evidence and sentenced the defendant to a longer term of incarceration than he could

requisite to imposition of such a sentence has been soundly rejected by prior decisions of this Court."” (quoting Clemons v. Mississippi, 494 U.S. 738, 745 (1990))).

55 FLA. STAT. § 921.141(1) (2010) ("Upon conviction or adjudication of guilt of a defendant of a capital felony, the court shall conduct a separate sentencing proceeding to determine whether the defendant should be sentenced to death or life imprisonment...."). Under the federal statute, by contrast, to be eligible for the death penalty, an aggravating (eligibility) factor must exist above and beyond the capital murder itself. 18 U.S.C. $\S$ 3593(e) (2010).

56 Apprendi v. New Jersey, 530 U.S. 466, 476 (2000) ("Our answer to that question was foreshadowed by our opinion in Jones $v$. United States . . ..”).

57 Given the Court's odd assertion in Jones that no one "today would claim that every fact with a bearing on sentencing must be found by a jury; we have resolved that general issue and have no intention of questioning its resolution," Jones v. United States, 526 U.S. 227, 248 (1999), Apprendi is perhaps no more than merely a consolidation of the holding in Jones. 
have received for the charge in question based solely on the facts he admitted in his plea. Apprendi, who had reserved his right to appeal the animus finding, did so, arguing that the fact that the hate crime allegation was found to be true by a judge rather than a jury deprived him of the rights guaranteed him by the Sixth and Fourteenth Amendments. ${ }^{58}$

Justice Stevens, writing for five Justices, reaffirmed the holding of Jones. He quoted his own concurring opinion in that case for the proposition that: " $[\mathrm{I}] \mathrm{t}$ is unconstitutional for a legislature to remove from the jury the assessment of facts that increase the prescribed range of penalties to which a criminal defendant is exposed. It is equally clear that such facts must be established by proof beyond a reasonable doubt." ${ }^{59}$ The Court left intact its decision in AlmendarezTorres v.United States $^{60}$ that an allegation of a prior conviction was a sentencing provision and not an element of the crime (and thus, presumably did not need to be proved to a jury and beyond a reasonable doubt), but its opinion was otherwise categorical: ${ }^{61}$ other than the fact of a prior conviction, any fact that increases the maximum possi-

58 As a defendant in state court, Apprendi's jury rights derived from the Fourteenth Amendment. See Barron v. Baltimore, 32 U.S. (7 Pet.) 243, 250 (1833) (holding that citizens cannot directly invoke the Bill of Rights against state governments); see also Jerold $\mathrm{H}$. Israel, Selective Incorporation: Revisited, 71 GEO. L.J. 253, 317 (1982) (“[T] he states were to receive no greater deference for their judgments than the federal government."); Justin F. Marceau, Un-Incorporating the Bill of Rights: The Tension Between the Fourteenth Amendment and the Federalism Concerns That Underlie Modern Criminal Procedure Reforms, 98 J. CRIM. L. \& CRIMINOLOGY 1231, 1251 (2008) ("There were not... any grounds for deferring to a state court's application of a 'lesser version of the same guarantee as applied to the Federal Government.”' (quoting Gideon v. Wainwright, 372 U.S. 335, 346-47 (1963) (Douglas, J., separate opinion))).

59 Apprendi, 530 U.S. at 490 (alteration in original) (quoting Jones, 526 U.S. at 252-53 (Stevens, J., concurring)). Justice Stevens also cited to Justice Scalia's concurring opinion in Jones. Id.

60 Almendarez-Torres v. United States, 523 U.S. 224, 246 (1998) ("[T]he remaining McMillan factors support the conclusion that Congress has the constitutional power to treat the feature before us ... as a sentencing factor ....").

61 The Court's defense of Almendarez-Torres was hardly full-throated:

Even though it is arguable that Almendarez-Torres was incorrectly decided, and that a logical application of our reasoning today should apply if the recidivist issue were contested, Apprendi does not contest the decision's validity and we need not revisit it for purposes of our decision today to treat the case as a narrow exception to the general rule we recalled at the outset. Given its unique facts, it surely does not warrant rejection of the otherwise uniform course of decision during the entire history of our jurisprudence.

Apprendi, 530 U.S. at 489-90 (footnotes omitted). 
ble penalty for a crime must be submitted to a jury and proved by the prosecution beyond a reasonable doubt. ${ }^{62}$

In clarifying and expanding its Jones holding, the Apprendi Court was again obligated to distinguish apparently contradictory capital precedents. Citing Walton - where the Court had upheld Arizona's capital sentencing scheme under which the judge determined whether the facts that make the defendant eligible for death are trueJustice Stevens argued that the reasoning of Jones and Apprendi did not prohibit a state from permitting a judge to find facts necessary to impose the penalty of death: "this Court has previously considered and rejected the argument that the principles guiding our decision today render invalid state capital sentencing schemes requiring judges, after a jury verdict holding a defendant guilty of a capital crime, to find specific aggravating factors before imposing a sentence of death." ${ }^{63}$

Why, exactly, the reasoning of Jones and Apprendi did not apply to capital sentencing was far from clear, however, as Justice O'Connor pointed out in her Apprendi dissent. She argued that the distinction that the Court drew between Apprendi and Jones, on the one hand, and Spaziano, Hilbin, and Walton on the other, could not be maintained: " $[\mathrm{t}]$ he distinction of Walton offered by the Court today is baffling, to say the least." ${ }^{, 4}$ As O'Connor read the Arizona statute at issue in Walton, it did exactly what the Court rejected in the New Jersey hate crime statute:

Under Arizona law, the fact that a statutory aggravating circumstance exists in the defendant's case "increases the maximum penalty for [the] crime" of first-degree murder to death. If the judge does not find the ex-

$62 I d$. at 490 ("Other than the fact of a prior conviction, any fact that increases the penalty for a crime beyond the prescribed statutory maximum must be submitted to a jury, and proved beyond a reasonable doubt.").

63 Id. at 496

$64 I d$. at 538 (O'Connor, J., dissenting). As Justice Kennedy quite rightly pointed out dissenting in Jones, the standard that the Supreme Court has adopted for determining what questions must go to a jury seems custom-suited to overturning a case like Walton:

If it is constitutionally impermissible to allow a judge's finding to increase the maximum punishment for carjacking by 10 years, it is not clear why a judge's finding may increase the maximum punishment for murder from imprisonment to death. In fact, Walton would appear to have been a better candidate for the Court's new approach than is the instant case.

Jones v. United States, 526 U.S. 227, 272 (Kennedy, J., dissenting). Of course, Kennedy and O'Connor were arguing that Jones and Apprendi were wrongly decided as inconsistent with the line of capital cases. Their arguments, however, would lead to the overturning of the capital precedents as inconsistent with the Sixth Amendment cases. 
istence of a statutory aggravating circumstance, the maximum punishment authorized by the jury's guilty verdict is life imprisonment. ${ }^{65}$

Justice O'Connor's criticism, of course, was not of the Arizona sentencing scheme but of the Court's own Sixth Amendment jurisprudence. $^{66}$ For her, the traditional role of the judge in determining a defendant's appropriate sentence was badly undercut by the Court's blind adherence to a perceived Sixth Amendment principle.

\section{The Sixth Amendment Cannot Be Home to Both}

The continuing tension between these two lines of Sixth Amendment cases-capital cases upholding the power of a judge to make the findings of fact that make one eligible for death and non-capital cases requiring that every fact that leads to greater possible punishment must be found by a jury and beyond a reasonable doubt-came to a head in 2002 in Ring. ${ }^{67}$ In Ring, the petitioner challenged the very Arizona capital statute that the Court had upheld in Walton and reaffirmed in Apprendi. The Arizona Supreme Court, in passing on Ring's challenge of the state's death penalty law, explicitly endorsed Justice O'Connor's reading of the Arizona capital statute. ${ }^{68}$ Under

65 Apprendi, 530 U.S. at 537 (O'Connor, J., dissenting) (citations omitted) (quoting Jones, 526 U.S. at 243 n.6) (internal quotation marks omitted). Ironically, the Court retorts by quoting Justice Scalia's opinion dissenting in Almendarez-Torres for the proposition that "once a jury has found the defendant guilty of all the elements of an offense which carries as its maximum penalty the sentence of death, it may be left to the judge to decide whether that penalty, rather than a lesser one, ought to be imposed." Id. at 497 (quoting Almendarez-Torres, 523 U.S. at 257 n.2 (Scalia, J., dissenting)).

66 The Arizona capital sentencing scheme described by Justice O'Connor is consistent with the Model Penal Code provision addressing capital punishment, § 210.6. Compare Apprendi, 530 U.S. at 536-37 (O'Connor, J., dissenting) (explaining that under Arizona law, a defendant can be sentenced to death only if the judge finds a statutory aggravating factor), with MODEL PENAL CODE $\$ 210.6$ (1980) ("The determination whether sentence of death shall be imposed shall be in the discretion of the Court. In exercising such discretion, the Court shall take into account the aggravating ... circumstances ...."). Following Gregg v. Georgia, 428 U.S. 153, 207 (1976), which upheld a capital sentencing system based loosely on that endorsed by the Model Penal Code, most states embraced a similar approach.

67 Ring v. Arizona, 536 U.S. 584, 588-89 (2002).

68 See State v. Ring (Ring I), 25 P.3d 1139, 1151 (Ariz. 2001) (en banc), rev'd, 536 U.S. at 548 (2002) ("In Arizona, a defendant cannot be put to death solely on the basis of a jury's verdict, regardless of the jury's factual findings. The range of punishment allowed by law on the basis of the verdict alone is life imprisonment with the possibility of parole or imprisonment for "natural life" without the possibility of release. It is only after a subsequent adversarial sentencing hearing, at which the judge alone acts as the finder of the necessary statutory factual elements, that a defendant may be sentenced to death. ... Therefore, the present case is precisely as described in Justice O'Connor's dissent-Defendant's death sentence required the judge's factual findings." (citations omitted) (citing ARIZ. REv. STAT. ANN. § 13-703.A-.E (2001))). 
Arizona law, the state high court found, a defendant cannot be sentenced to death unless a judge, sitting without a jury, determines that at least one aggravating circumstance has been proven true beyond a reasonable doubt. ${ }^{69}$ Although the Arizona court appeared to believe that the statute, properly interpreted, ran afoul of Apprendi, it rejected Ring's Sixth Amendment challenge in light of the Supreme Court's explicit reaffirmance of Walton in that very case. ${ }^{70}$

On appeal, the U.S. Supreme Court reversed, finding that the Arizona statute, as interpreted by the state high court, ran afoul of the Sixth Amendment as read by the Jones and Apprendi Courts. ${ }^{71}$ Echoing the opinion of the Arizona Supreme Court, the United States Supreme Court rightly noted that once a capital defendant had been convicted of capital murder in Arizona, the most serious punishment he can receive is life without parole; he does not become eligible for death until at least one aggravating factor is found. Because Arizona law calls for this finding to be made by a judge sitting without a jury, the Arizona statute ran afoul of the Court's opinion in Apprendi. In a memorable phrase, Justice Ginsburg wrote for the Court: "we hold that Walton and Apprendi are irreconcilable; our Sixth Amendment jurisprudence cannot be home to both. Accordingly, we overrule Walton to the extent that it allows a sentencing judge, sitting without a jury, to find an aggravating circumstance necessary for imposition of the death penalty."

As he would again in United States v. Booker, ${ }^{73}$ Justice Breyer attempted in his concurrence to soften Ring's blow. Breyer, who did

69 Id. Apprendi recognizes that the jury right is a "companion" to the beyond a reasonable doubt standard of proof under Winship. Apprendi, 530 U.S. at 478 ("Equally well founded is the companion right to have the jury verdict based on proof beyond a reasonable doubt."). Accordingly, after Ring, the prosecutorial burden of proof as to an aggravator is beyond a reasonable doubt. Compare Apodaca v. Oregon, 406 U.S. 404, 411 (1972) (" $[\mathrm{T}]$ he Sixth Amendment itself has never been held to require proof beyond a reasonable doubt...."), with Apprendi, 530 U.S. at 478 (describing the Sixth Amendment jury protection as "the companion right to have the jury verdict based on proof beyond a reasonable doubt" (emphasis added)), and Priya Nath, Case Note, Sattazahn v. Pennsylvania 123 S. Ct. 732 (2003), 15 CAP. DEF. J. 419, 422 (2003) ("[T]he Ring Court held that the Sixth Amendment requires a jury to find the existence of aggravating factors beyond a reasonable doubt.”).

$70 \quad$ Ring I, 25 P.3d at 1152 (concluding that Walton is the controlling authority).

$71 \quad$ Ring, 536 U.S. at 609.

$72 \quad I d$.

73 United States v. Booker, 543 U.S. 220 (2005). Although Justice Breyer dissented from the Court's holding that the federal sentencing guidelines were unconstitutional, he managed to exert substantial influence over what is now considered the Booker rule because his opinion regarding the proper remedy commanded a five Justice majority. See id. at 258-59 (setting out the three-part rule which lays out what portions of the statute are to be retained); see also Douglas A. Berman, Tweaking Booker: Advisory Guidelines in the Feder- 
not join Justice Ginsberg's majority opinion, began by expressing his continued disapproval of the Court's decision in Apprendi. He concurred in the result, however, because he believed that the jury's role in capital cases is mandated by the Eighth Amendment rather than the Sixth: "the Eighth Amendment requires individual jurors to make, and to take responsibility for, a decision to sentence a person to death." ${ }^{74}$ For Justice Breyer, therefore, the heightened due process required in capital cases necessarily includes a determination by the jury whether retribution requires the imposition of a sentence of death against the defendant; only retribution, Breyer argued, could justify the imposition of a sentence of death rather than some lesser punishment, and only a jury was properly situated to determine whether society's ultimate punishment is justified in a particular case. $^{75}$

Justice Scalia, who did join the majority opinion, also concurred separately largely to make clear his disagreement with Justice Breyer's understanding of the basis for the Court's opinion:

While I am, as always, pleased to travel in Justice Breyer's company, the unfortunate fact is that today's judgment has nothing to do with jury sentencing. What today's decision says is that the jury must find the existence of the fact that an aggravating factor existed. Those States that leave the ultimate life-or-death decision to the judge may continue to do

al System, 43 Hous. L. REv. 341, 346 (2006) (examining "Justice Breyer's remedial opinion"). The softening that occurred at the hands of Justice Breyer's remedial opinion is somewhat hard to grasp; the remedy for a sentencing under an unconstitutional system of federal sentencing guidelines was to declare the entire guideline system advisory. See Douglas A. Berman, Conceptualizing Booker, 38 ARIz. ST. L.J. 387, 410 (2006) (describing the Booker remedy as greatly enhancing judges' discretion at sentencing). Of course, the sort of far-reaching discretion permitted (and mandated) after Booker is not permissible in the Eighth Amendment capital sentencing context. See Furman v. Georgia, 408 U.S. 238, 256-57 (1972) ("[T]hese discretionary statutes are unconstitutional in their operation.”). Thus, a faithful application of the Ring jury-right to capital sentencing might provide capital defendants with the benefits of the Apprendi line of cases, without the oft complained of arbitrariness of the Booker remedy.

74 Ring, 536 U.S. at 619 (Breyer, J., concurring). Notably, the argument that the Eighth Amendment requires jury sentencing in capital cases was not even advanced by counsel for the defendant in cases like Spaziano. See Spaziano v. Florida, 468 U.S. 447, 458 (1984) ("Petitioner points out that we need not decide whether jury sentencing in all capital cases is required; this case presents only the question whether, given a jury verdict of life, the judge may override that verdict and impose death.").

75 Ring, 536 U.S. at 615-16 (Breyer, J., concurring) ("[Jurors] are more likely to 'express the conscience of the community on the ultimate question of life or death,' and better able to determine in the particular case the need for retribution, namely, 'an expression of the community's belief that certain crimes are themselves so grievous an affront to humanity that the only adequate response may be the penalty of death." (citations omitted) (quoting Gregg v. Georgia, 428 U.S. 153, 184 (1976); Witherspoon v. Illinois, 391 U.S. $510,519(1968)))$. 
so-by requiring a prior jury finding of aggravating factor in the sentencing phase or, more simply, by placing the aggravating-factor determination (where it logically belongs anyway) in the guilt phase. There is really no way in which Justice Breyer can travel with the happy band that reaches today's result unless he says yes to Apprendi. Concisely put, Justice Breyer is on the wrong flight; he should either get off before the doors close, or buy a ticket to Apprendi-land. ${ }^{76}$

The disagreement between Justices Scalia and Breyer in Ring, therefore, comes down to nothing less than a determination of what the jury right entails in capital cases and from where in the Constitution this right derives. Is the jury guarantee merely about a defendant's right to have the facts that condemn him found by a jury, or is it a more robust "death is different" rule based in the jury's role as moral conscience of the community? As the following sections reveal, Justice Scalia's view-that Ring is merely about fact finding-has largely carried the day. We demonstrate the negative consequences of the triumph of the Justice Scalia's reading and encourage the Court to give more credence to Justice Breyer's reading in order to realize the promise of the jury's role in capital sentencing.

\section{UNDERSTANDING THE EIGHTH AMENDMENT'S CAPITAL SENTENCING REQUIREMENTS IN LIGHT OF THE SIXTH AMENDMENT JURY RIGHT}

\section{A. The Capital Sentencing Landscape Today}

The buildup to Ring saw the Supreme Court ironing out the tensions between its non-capital Sixth Amendment decisions-which trumpeted the role of the jury-and its Eighth Amendment capital decisions-which largely minimized the jury's role in sentencing. ${ }^{77}$ Whereas Jones and Apprendi were content to allow questions of capital

76 Id. at 612-13 (Scalia, J., concurring); see also Sundby, supra note 36, at 1148 (explaining that Justice Scalia finds the principles of guided discretion and individualized consideration to be in conflict with each other).

77 Indeed, in the Eighth Amendment context, the Court has affirmatively celebrated the role of the judge over the jury in sentencing on several occasions. Compare Maynard v. Cartwright, 486 U.S. 356, 363-64 (1988) (holding that Oklahoma's statutory standard for applying the death penalty was too vague), and Godfrey v. Georgia, 446 U.S. 420, 432-33 (1980) (holding that Georgia's statutory factors did not help judges or jurors avoid arbitrary death sentences), with Walton v. Arizona, 497 U.S. 639, 653 (1990) ("When a jury is the final sentencer, it is essential that the jurors be properly instructed regarding all facets of the sentencing process.... But the logic of those cases [Godfrey v. Georgia and Maynard v. Cartwright] has no place in the context of sentencing by a trial judge. Trial judges are presumed to know the law and to apply it in making their decisions."), overruled in part by Ring v. Arizona, 536 U.S. 584 (2002). 
sentencing to be governed exclusively by the Eighth Amendment's prohibition on cruel and unusual punishment, Ring made clear that the Court's capital punishment jurisprudence must accommodate its Sixth Amendment jurisprudence (rather than vice versa). However, the recognition that capital sentencing must comport with the dictates of the Sixth Amendment was only half a victory for criminal defendants; clarifying what, exactly, the Sixth Amendment means in the capital punishment context remains no easy feat.

Here's what we do know: the Supreme Court currently reads the Eighth Amendment as imposing two distinct procedural protections designed to narrow the class of persons who will be sentenced to death and ensure that meaningful distinctions are made between those defendants who will live and those who will be executed: (1) the states must have a process for measuring the relative aggravation of the offences; and 2) the trier of fact in a capital case must consider any factor relevant to the particular defendant's culpability so as to limit the class of persons eligible for the ultimate penalty. ${ }^{78}$ These are the twin requirements of the Gregg and Woodson lines of cases, the requirements that Justice Scalia argued could not be reconciled with one another. And the states, in attempting to comply with these twin requirements, have constructed similar, but subtly varied, death penalty statutes.

With regard to the first of these requirements-the making of meaningful distinctions-states generally ask juries to determine whether one or more aggravating factors are present: whether the crime was committed for pecuniary gain, whether it involved the intentional infliction of great pain, whether it involved multiple or vulnerable victims, etc. ${ }^{79}$ Knowing that they may neither impose the

78 The Court has never held that these two requirements alone are sufficient to comply with the Eighth Amendment requirement of procedural regularity and fairness. Indeed, in upholding the capital sentencing systems of various states in Gregg and the accompanying cases, the Court seemed to recognize that each state's "peculiar mix of procedural protections," considered in the aggregate, was sufficient to comply with the Eighth Amendment. Steiker \& Steiker, supra note 17, at 363. The Court emphasized, for example, the importance of channeling sentence discretion and proportionality reviews as distinct and separate requirements from the narrowing rules imposed by Gregg and Woodson. Id. at 363, 379 (explaining that among other procedural requirements that seemed essential to the Eighth Amendment in the wake of Gregg, the Court has "emphatically disclaimed any separate requirement to channel discretion"). Likewise, the Court admitted that it no longer requires proportionality review in all cases. See Pulley v. Harris, 465 U.S. 37, 50-51 (1984) ("There is thus no basis in our cases for holding that comparative proportionality review by an appellate court is required in every case in which the death penalty is imposed and the defendant requests it.").

79 See, e.g., TENn. CodE ANn. § 39-13-204(i) (1)-(14) (2010) ("No death penalty or sentence of imprisonment for life without possibility of parole shall be imposed but upon a un- 
death penalty on all murderers nor leave the question of which murderers are most deserving of death to the unfettered discretion of a trier of fact, the states have followed the lead of the Model Penal Code's capital provisions, using aggravating circumstances to determine death eligibility. ${ }^{80}$ There is little unanimity regarding exactly what factors make a defendant death-eligible, however, and the $\mathrm{Su}$ preme Court has spent a good part of the last thirty-five years determining the constitutionality of the varied aggravating factors used by the nation's death penalty states. ${ }^{81}$

With regard to the second of the Supreme Court's Eighth Amendment requirements- that triers of fact consider any factor that the defendant believes to be mitigating of his culpability-the states also follow similar if slightly divergent paths. They generally ask triers of fact to consider any proffered mitigating evidence against the government's case in aggravation and to determine whether, on balance, the evidence supports a punishment of life imprisonment or death. ${ }^{82}$

animous finding that the state has proven beyond a reasonable doubt the existence of one (1) or more of the statutory aggravating circumstances, which are limited to the following ....").

80 See MODEL PENAL CODE $\$ 210.6$ (1980) (listing various aggravating factors that courts and juries should consider in contemplating whether to sentence death). As one commentator has observed, "The MPC approach did not initially attract much political support, but in the wake of ... Furman $v$. Georgia, ... the MPC's approach has essentially become the law of the land in jurisdictions that continue to use the death penalty." Gerard E. Lynch, Revising the Model Penal Code: Keeping It Real, 1 OHIO ST. J. CRIM. L. 219, 232 (2003). In 2009, the American Law Institute (ALI) withdrew its support of the Model Penal Code death penalty provision and Michael Traynor, President Emeritus of the ALI, has called this "a striking repudiation from the very organization that provided the blueprint for death penalty laws in this country." Michael Traynor, Opinion, The Death Penalty-It's Unworkable, L.A. TIMES, Feb. 4, 2010, http://articles.latimes.com/2010/feb/04/ opinion/la-oe-traynor4-2010feb04 (discussing the difficulties of imposing a fair death penalty system).

81 See Godfrey, 446 U.S. at 432 (holding that a provision of the Georgia Code permitting the imposition of the death penalty if the offense is "wantonly vile, horrible or inhuman" is unconstitutionally vague as applied); see also Maynard, 486 U.S. at 361-62 (concluding that the analysis of vagueness directed at aggravating circumstances differs from the Due Process Clause approach to vagueness).

82 The cumulative breadth of the available aggravating (eligibility) factors in many states has led commentators to conclude that the narrowing function of aggravating factors, as required by Furman, has been effectively negated. See, e.g., Jeffrey L. Kirchmeier, Aggravating and Mitigating Factors: The Paradox of Today's Arbitrary and Mandatory Capital Punishment Scheme, 6 WM. \& MARY BILL RTS. J. 345, 348-49 (1998) (arguing that the aggregate effect of so many aggravating factors is to eliminate any meaningful narrowing function, and concluding that only a mandatory death penalty system would actually eliminate the arbitrariness concerns raised in Furman); id. at 356-57 (suggesting that the Court no longer takes seriously the requirement that death sentences not be arbitrary); Steiker \& Steiker, supra note 17, at 374 (identifying a key failure of the use of aggravators for narrowing as the Court's failure to place any "outer limit on the number of aggravating factors that a 
While the states can be roughly categorized into weighing stateswhich limit the factors that may be considered in aggravation-and non-weighing states-which do not place limits on the factors considered in aggravation-there is a fair amount of variation in how the states ask triers of fact to engage in this balancing. ${ }^{83}$ In considering a variety of state selection schemes, the Supreme Court has held that the Eighth Amendment does not require any one particular means of balancing aggravating and mitigating factors. ${ }^{84}$

\section{B. The Sixth Amendment Jury Right in Four Representative States}

While the Supreme Court has held that many state sentencing regimes pass Eighth Amendment scrutiny, this section is concerned with whether the Sixth Amendment jury right is implicated in lesser or greater ways by the states' diverse approaches to determining the ultimate sentence in a capital case. ${ }^{85}$ The Supreme Court has been

state may adopt. Thus, even if a state adopts aggravating factors that, taken individually, meaningfully narrow the class of the death-eligible, the factors collectively might render virtually all murderers death-eligible").

83 There is significant confusion regarding the proper meaning of these categories; however, for our purposes, the distinction is not material. For what it is worth, the Court has identified Mississippi as a paradigmatic example of a weighing state because it is a state where the aggravators or eligibility factors, and only these factors, are weighed against the applicable mitigating evidence to assess whether a death sentence is permissible. Brown v. Sanders, 546 U.S. 212, 217-18 (2006) ("We identified as 'weighing State[s]' those in which the only aggravating factors permitted to be considered by the sentencer were the specified eligibility factors."). The two pans of the scale, then, are weighted with discrete and limited categories of evidence-on the mitigation side is whatever evidence was admitted in mitigation during the penalty phase and on the aggravation side are only the factor or factors found in aggravation at the eligibility stage of the proceeding. By contrast, the Court has explained that a non-weighing state is a state that permits the sentencer to balance against the applicable mitigation evidence any relevant evidence in aggravation, not just the proven eligibility or aggravating factors. Id.; see also John $\mathrm{H}$. Blume et al., Probing "Life Qualification" Through Expanded Voir Dire, 29 HofsTRA L. REv. 1209, 1225-28 n.68 (2001) (denoting the differences between "weighing states" and "nonweighing states"). Accordingly, the distinction between weighing and non-weighing lies not in whether weighing occurs, but in what is weighed.

84 See, e.g., Kansas v. Marsh, 548 U.S. 163, 175 (2006) (“[W]e have never held that a specific method for balancing mitigating and aggravating factors in a capital sentencing proceeding is constitutionally required. Rather, this Court has held that the States enjoy a constitutionally permissible range of discretion in imposing the death penalty." (citation omitted) (internal quotation marks omitted)). The distinction between weighing and nonweighing, though not of constitutional significance in itself, is of considerable importance when, on appeal, an aggravating factor is deemed invalid. Compare Zant v. Stephens, 462 U.S. 862, 878 (1983) (addressing the problem in the context of a non-weighing state), with Clemons v. Mississippi, 494 U.S. 738, 745 (1990) (addressing the problem in the context of a weighing state).

85 The balancing phase, as the term is used in this Article, refers to that portion of the sentencing proceeding where a defendant has already been deemed "eligible" for a death 
largely silent on this point since Ring, and the lower courts are generally divided as to the scope of Ring's protections during the sentencing phase of capital trials. ${ }^{86}$ We examine the Sixth Amendment implications in four states-Florida, Texas, California and Georgiathat are notable both as very active death penalty states ${ }^{87}$ and as states with sentencing systems that illustrate the unanswered constitutional questions that remain so many years after Ring.

\section{Florida}

Consider, first, the capital statute of Florida, a statute that the Supreme Court, prior to Ring, found on multiple occasions complies with the dictates of the Eighth Amendment. ${ }^{88}$ The Florida statute be-

sentence based on the finding of one or more aggravating factors and the question is whether the evidence in mitigation outweighs the evidence in aggravation.

86 Compare United States v. Barrett, 496 F.3d 1079, 1107 (10th Cir. 2007) ("[T]he Apprendi/Ring rule should not apply here because the jury's decision that the aggravating factors outweigh the mitigating factors is not a finding of fact. Instead, it is a 'highly subjective,' 'largely moral judgment' 'regarding the punishment that a particular person deserves...." (alteration in original) (quoting Caldwell v. Mississippi, 472 U.S. 320, 340 n.7 (1985))), and United States v. Sampson, 486 F.3d 13, 32 (1st Cir. 2007) ("[T]he weighing of aggravators and mitigators does not need to be 'found.'”), and United States v. Fields, 483 F.3d 313, 346 (5th Cir. 2007) (“[T]he Sixth Amendment does not require a jury to be instructed that it must find that the aggravating factors outweigh the mitigating factors beyond a reasonable doubt."), and State v. Barker, 809 N.E.2d 312, 315 (Ind. 2004) (" $[\mathrm{T}]$ here is no constitutional requirement that the weighing factor be found beyond a reasonable doubt...."), and Ritchie v. State, 809 N.E.2d 258, 266 (Ind. 2004) ("Neither federal constitutional doctrine under Apprendi and Ring nor Indiana state jurisprudence leads to the requirement that weighing be done under a reasonable doubt standard."), and Oken v. State, 835 A.2d 1105, 1158 (Md. 2003) (“[T] he weighing process never was intended to be a component of a 'fact finding' process ....”), and State v. McLaughlin, 265 S.W.3d 257, 264 (Mo. 2008) (en banc) (upholding a judge's imposition of the death sentence after the jury was deadlocked regarding whether the mitigating evidence did not outweigh aggravating evidence), with Johnson v. State, 59 P.3d 450, 460 (Nev. 2002) (concluding that the weighing of aggravating and mitigating factors is "in part a factual determination"), and William J. Bowers et al., The Decision Maker Matters: An Empirical Examination of the Way the Role of the Judge and the Jury Influence Death Penalty Decision-Making, 63 WASH. \& LEE L. REv. 931, 940 ("The rationale of Ring would seem ... to require that jurors decide the relative weight or sufficiency of aggravating and mitigating factors.").

87 See Michael Mello, Certain Blood for Uncertain Reasons: A Love Letter to the Vermont Legislature on Not Reinstating Capital Punishment, 32 VT. L. REv. 765, 818 (2008) (calling Texas the "buckle of the death belt"); $i d$. at 784 (noting that both Georgia and Florida are "active capital punishment states"); $i d$. at 804 (asserting that California has the "largest death row ... in the western hemisphere").

88 See Spaziano v. Florida, 468 U.S. 447, 462-63 (1984) (concluding that a death sentence need not be imposed by a jury); Barclay v. Florida, 463 U.S. 939, 958 (1983) (asserting that individualized determinations on the imposition of the death penalty are permissible); Proffitt v. Florida, 428 U.S. 242, 247 (1976) (rejecting the argument that the imposition of the death penalty under any circumstances is cruel and unusual punishment). 
gins with a straightforward weighing procedure, but adds a twist that has serious Sixth Amendment implications. Florida Statute Section 775.082 states that:

(1) A person who has been convicted of a capital felony shall be punished by death if the proceeding held to determine sentence according to the procedure set forth in s. 921.141 results in findings by the court that such person shall be punished by death, otherwise such person shall be punished by life imprisonment and shall be ineligible for parole. ${ }^{89}$

Section 921.141 provides for a sentencing hearing to be held before the trial court. At the end of the sentencing hearing, the jury is to determine: "whether sufficient aggravating circumstances exist;" "whether sufficient mitigating circumstances exist" to outweigh the

$89 \quad$ FLA. STAT. $\$ 775.082(2010)$.

90 FLA. STAT. $\$ 921.141$ (2) (2010). The statute lists the following aggravating factors:

(a) The capital felony was committed by a person previously convicted of a felony and under sentence of imprisonment or placed on community control or on felony probation.

(b) The defendant was previously convicted of another capital felony or of a felony involving the use or threat of violence to the person.

(c) The defendant knowingly created a great risk of death to many persons.

(d) The capital felony was committed while the defendant was engaged, or was an accomplice, in the commission of, or an attempt to commit, or flight after committing or attempting to commit, any: robbery; sexual battery; aggravated child abuse; abuse of an elderly person or disabled adult resulting in great bodily harm, permanent disability, or permanent disfigurement; arson; burglary; kidnapping; aircraft piracy; or unlawful throwing, placing, or discharging of a destructive device or bomb.

(e) The capital felony was committed for the purpose of avoiding or preventing a lawful arrest or effecting an escape from custody.

(f) The capital felony was committed for pecuniary gain.

(g) The capital felony was committed to disrupt or hinder the lawful exercise of any governmental function or the enforcement of laws.

(h) The capital felony was especially heinous, atrocious, or cruel.

(i) The capital felony was a homicide and was committed in a cold, calculated, and premeditated manner without any pretense of moral or legal justification.

(j) The victim of the capital felony was a law enforcement officer engaged in the per-formance of his or her official duties.

(k) The victim of the capital felony was an elected or appointed public official engaged in the performance of his or her official duties if the motive for the capital felony was related, in whole or in part, to the victim's official capacity.

(1) The victim of the capital felony was a person less than 12 years of age.

(m) The victim of the capital felony was particularly vulnerable due to advanced age or disability, or because the defendant stood in a position of familial or custodial authority over the victim.

(n) The capital felony was committed by a criminal gang member, as defined in s. 874.03.

(o) The capital felony was committed by a person designated as a sexual predator pursuant to $\mathrm{s} .775 .21$ or a person previously designated as a sexual predator who had the sexual predator designation removed. Id. $§ 921.141(5)$. 
aggravating factors; and, "based on these considerations, whether the defendant shall be sentenced to life ... or death." ${ }^{91}$

Up to this point, the statute resembles a classic, post-Gregg capital sentencing provision. The state has enumerated certain aggravating factors and has made a finding of one of those circumstances a prerequisite to the imposition of the penalty of death. This is also clearly a weighing statute- the aggravating factors found, and only those factors, are to be balanced against whatever mitigating evidence a defendant has placed before the jury for its consideration.

After requiring the jury to balance the eligibility factors against the mitigating factors, the Florida statute next commands a step that is a deviation from the procedures of most other weighing statutes and that brings the question of Ring's applicability into sharp relief. For in Florida, the judge, rather than the jury, ultimately determines the defendant's sentence:

Notwithstanding the recommendation of a majority of the jury, the court, after weighing the aggravating and mitigating circumstances, shall enter a sentence of life imprisonment or death, but if the court imposes a sentence of death, it shall set forth in writing its findings upon which the sentence of death is based as to the facts.

In other words, regardless of the decisions of the jury regarding the presence of aggravating factors and the extent to which they outweigh the case in mitigation, the trial judge is to re-balance these factors and determine anew whether death or life is merited.

\section{a. Death Eligibility Under Florida Law}

Because of the role afforded to the judge in determining whether the defendant ultimately lives or dies, in Florida, the Ring question is more than merely rhetorical. Recall that Ring requires that any fact that is necessary for the imposition of a sentence of death be found by a jury; if the second part of the Florida statute allows a criminal defendant to be sentenced to death based upon judicial fact finding, then it runs afoul of Ring's mandate. In order to understand the applicability of the Sixth Amendment to Florida's capital statute, therefore, it is necessary to determine what facts must be determined before an individual can be sentenced to death.

Let us begin with the first question for the trier of fact: whether a sufficient aggravating factor exists. The determination is unquestionably a factual conclusion that makes a defendant eligible for the 
death penalty. In the absence of such a finding, the highest penalty that can permissibly be imposed upon a capital defendant is life in prison. In this way, the Florida statue is operationally identical to the Arizona statute described in both Walton and Ring. Accordingly, the plain language of Ring makes clear that the determination of an aggravating factor must be made by a jury and beyond a reasonable doubt. ${ }^{93}$

Despite Ring's unambiguous, black-letter mandate that a jury make the factual finding with regard to the initial aggravating (eligibility) factors, the Florida Supreme Court's reading of its own statute appears to come to a different conclusion. For example, in State $v$. Steele, ${ }^{94}$ the Florida high court rejected the use by a trial court of special verdict forms in a capital sentencing hearing. The trial court had ordered the advisory jury to fill out verdict forms in order to ensure that a majority of the jury agreed on the presence of at least one of the aggravating factors alleged. The prosecution appealed this ruling and the Florida Supreme Court held that a majority vote with regard to any single aggravating factor was not required by Florida Law; in fact, it held that the use of special verdict forms would be error under the statute:

Nothing in the statute, the standard jury instructions, or the standard verdict form, however, requires a majority of the jury to agree on which aggravating circumstances exist. Under the current law, for example, the jury may recommend a sentence of death where four jurors believe that only the "avoiding a lawful arrest" aggravator applies, while three others believe that only the "committed for pecuniary gain" aggravator applies, because seven jurors believe that at least one aggravator applies.... Unless and until a majority of this Court concludes that Ring applies in Florida, and that it requires a jury's majority (or unanimous) conclusion that a particular aggravator applies, or until the Legislature amends the statute ... the court's order imposes a substantive burden on the state not found in the statute and not constitutionally required. ${ }^{95}$

This understanding of the jury right is irreconcilable with the Sixth Amendment for at least two independent reasons.

93 What is interesting about the Florida statute, however, is that it is not clear whether the jury's finding of aggravating factors may be disturbed by the trial judge. While the jury must determine whether sufficient aggravating factors exist and whether those factors outweigh the case in mitigation, the trial judge is given a more limited task; her role is limited to weighing the aggravating and mitigating factors against one another. See id. Of course, not even this part of the statute is clear: the same section states that a judge determining that the defendant should be sentenced to death must "set forth in writing its findings upon which the sentence of death is based as to the facts ... [t] hat sufficient aggravating circumstances exist." Id.

94921 So. 2d 538 (Fla. 2005).

95 Id. at 545-46 (citations omitted). 
First, the passage quoted above demonstrates that although a finding of an aggravating factor is clearly a prerequisite to the imposition of the death penalty in Florida, the state's high court has refused to hold that Ring applies to such a finding. In fact, the Court explained that Ring's application, if any, to Florida's capital sentencing scheme "remains unclear." ${ }^{96}$ Stated another way, in Florida, a person might be sentenced to death although the jury fails to unanimously agree on the existence of a single aggravating factor; indeed, a sentence of death might be imposed even if the jury does not agree on the existence of any aggravating factors.

Consider, for example, a case in which the jury recommends a sentence of life, but the judge rejects this recommendation and imposes a death sentence. ${ }^{97}$ This is no idle possibility: "[b] etween 1972 and early 1992, Florida trial judges imposed death sentences over 134 juries' recommendations of life imprisonment." 98 A jury's rejection of the death penalty in such a case could mean one of two things: either the jury found no aggravators to be present or it found an aggravator to be present but concluded that the case in mitigation outweighed the case in aggravation. A judge's rejection of the jury's life verdict in the first alternative clearly violates Ring; aggravating factors are a prerequisite to the imposition of the death penalty and those factors must be found by a jury and not a judge. If, however, the jury imposed life because it believes that aggravators were present but outweighed by the case in mitigation, the applicability of Ring is less

96 Id. at 540 ("Since Ring, this Court has not yet forged a majority view about whether Ring applies in Florida.").

97 Proffitt v. Florida 428 U.S. 242, 249-50 (1976) (noting that the Florida Supreme Court has expressly approved the practice of imposing a sentence of death "following a jury recommendation of life" (citing Tedder v. State, 322 So. 2d 908, 910 (Fla. 1975))); see Harris v. Alabama, 513 U.S. 504, 521 (1995) (Stevens, J., dissenting) (“[J]udges are far more likely than juries to impose the death penalty. This has long been the case, and the recent experience of judicial overrides confirms it. Alabama judges have vetoed only five jury recommendations of death, but they have condemned 47 defendants whom juries would have spared."); see also Thompson v. State, 328 So. 2d 1, 5 (Fla. 1976) (noting judge-imposed death sentence despite jury recommendation of life); Douglas v. State, 328 So.2d 18, 20 (Fla. 1976) (noting that judge imposed a sentence of death, finding "that there were no mitigating circumstances," after jury recommended life sentence).

98 Harris, 513 U.S. at 521-22 n.8 (Stevens, J., dissenting). It does not appear that there are any reported cases in Florida that reflect this factual scenario post-Ring. See Inmate Legal Status, FLA. COMM'N ON CAPITAL CASES, http://www.floridacapitalcases.state.fl.us/cinmate-status.cfm\#W (last visited Feb. 18, 2011) (listing the present appellate status for each of Florida's death penalty cases). In this regard, Florida's system is, as applied, not violating the core requirement of Ring, by stripping from the jury the very sort of fact finding at issue in Ring. 
clear. $^{99}$ The problem, of course, is that without a special verdict, a sentencing judge can never know for sure whether the jury found an aggravating factor. ${ }^{100}$ Consequently, although Florida's advisory verdict sentencing system is not facially unconstitutional, if a judge ignores a life sentence returned by the jury and replaces it with a sentence of death, Ring is violated. ${ }^{101}$

We believe that Florida's approach to eligibility facts is inconsistent with the Supreme Court's Sixth Amendment jurisprudence for a second reason. Because a mitigator, unlike an aggravator, does not make a defendant eligible for an increased punishment (death), it is not the kind of fact that needs to be found by a jury under Ring. As a result, a number of states have concluded that the Sixth Amendment applies to findings of aggravators but not to findings of mitigators. There are other explanations for this disparate treatment, but one persuasive basis upon which state courts have distinguished aggravator findings from mitigator determinations is that findings as to mitigators do not require the sort of unanimity required of other substantive criminal law elements. ${ }^{102}$ Explaining this distinction, the Arizona Supreme Court has emphasized that "each juror may vote for a sentence of death-or against it—as each sees fit in light of the aggravating factors found by the jury and the mitigating evidence found by each juror." ${ }^{103}$ Whereas elements and their functional equivalent, including eligibility factors, must be found by the jury as a whole, facts in mitigation do not require any consensus as to a particular mitigator, but rather require each individual juror to determine for herself whether a mitigator or set of mitigators was sufficiently substantial to justify a life sentence. ${ }^{104}$

99 We discuss the applicability of Ring to Florida's selection process in the next section. See infra Part III.B.1.b.

100 Under Florida law, when the trial judge imposes a sentence of death, the judge must issue a written statement describing the circumstances, presumably including aggravating facts, that justify a sentence of death. FLA. STAT. § 921.141(3) (2010).

101 Cf. Espinosa v. Florida, 505 U.S. 1079, 1082 (1992) (per curiam) (holding that because a trial judge must give "great weight" to a jury's advisory sentence, when the jury is instructed on an invalid eligibility factor, even though it is impossible to know whether the jury relied on that particular invalid aggravator, the death sentence imposed by the judge is invalid).

102 See, e.g., Ex Parte Waldrop, 859 So. 2d 1181, 1190 (Ala. 2002) (distinguishing finding of mitigator from finding of element); Commonwealth v. Chambers, 807 A.2d 872, 883 (Pa. 2002) (holding that Pennsylvania law does not require the jury to find mitigators unanimously, and holding jury instruction requiring jurors to all find the same mitigator prejudicial error).

103 State ex rel. Thomas v. Granville, 123 P.3d 662, 665 n.3 (Ariz. 2005) (emphasis added).

$104 I d$. at 666. 
The Florida sentencing system turns the logic of the Arizona high court's approach on its head. Under Florida's system, the facts in aggravation-which serve the role of an element by rendering one eligible for greater punishment ${ }^{105}$-need not be found unanimously. Indeed, the Florida high court has held that a special verdict form specifying which, if any, eligibility factors were unanimously found is impermissible as a matter of Florida law. ${ }^{106}$ But if aggravators are functionally equivalent to elements, then the court's conclusion in this regard-that a death sentence is permissible so long as a majority of the jury believes that some aggravating factor is present, even if a majority of the jury rejects each of the factors-is valid only if it would apply to the elements of an offense. However, the U.S. Supreme Court has held just the opposite with regard to elements of an offense: a jury must be sufficiently unanimous ${ }^{107}$ as to each element. Thus, because eligibility factors are elements of a death sentence, they must be treated like elements with regard to unanimity. ${ }^{108}$

105 Blakely v. Washington, 542 U.S. 296, 303 (2004) (“[T] he 'statutory maximum' for Appren$d i$ purposes is the maximum sentence a judge may impose solely on the basis of the facts reflected in the jury verdict or admitted by the defendant."). As Professor John Douglass has observed, under "the language of Blakely, no judge-or jury for that matter-may impose death 'solely on the basis of the facts reflected' in the finding of death eligibility." John G. Douglass, Confronting Death: Sixth Amendment Rights at Capital Sentencing, 105 Colum. L. REV. 1967, 2004 (2005).

106 The Court also explained that such a system would be an "unnecessary expansion of Ring." State v. Steele, 921 So. 2d 538, 546 (Fla. 2005).

107 Although most jurisdictions, including the federal system, require unanimous jury verdicts, FED. R. CRIM. P. 31(a), the Constitution does not require unanimous verdicts in state criminal trials. See Apodaca v. Oregon, 406 U.S. 404, 410-12 (1972) (plurality opinion) (reviewing a 10-2 conviction and concluding that the Sixth Amendment jury right does not require unanimity in state criminal trials); Johnson v. Louisiana, 406 U.S. 356, 362 (1972) (reviewing a 9-3 conviction and concluding that because a "substantial majority" of the jury voted to convict, due process was not violated).

108 This aspect of Florida's sentencing scheme could be salvaged if capital eligibility facts were regarded as "means" of establishing eligibility as opposed to elements of capital murder. See Schad v. Arizona, 501 U.S. 624, 637 (1991) (plurality opinion). In a plurality with no clear narrowest grounds, the Court upheld a murder conviction that did not require the jury to be unanimous as to the "means"-i.e., premeditated or felony murderof the commission of the crime. Id. at 631 ("We have never suggested that in returning general verdicts in such cases the jurors should be required to agree upon a single means of commission."). Setting aside the potential impact of changes of Court personnel on this badly fractured decision, there are at least three reasons that non-unanimity as to an aggravating factor is not easily understood as a natural extension of Schad v. Arizona: (1) the Apprendi line of cases sought to end the sort of formalism that permits an element to be characterized as a mere sentencing factor, Apprendi v. New Jersey, 530 U.S. 466, 485 (2000), and relabeling what Ring has called the functional equivalent of an element as a mere "means" of establishing capital eligibility seems to similarly exalt form over substance; (2) the Schad plurality expressly noted that due process imposes limits on the ability of a crime to be defined in terms of wildly divergent "means"; that is to say, a crime 


\section{b. The Selection Decision Under Florida Law}

What, then, of the next question posed to the trier of fact under the Florida statute: whether sufficient mitigating factors exist to justify the imposition of an indeterminate life sentence rather than a death sentence? Is the absence of sufficient mitigation a "fact" that needs to be found by a jury or is it something else? As to this question as well, Florida has held that Ring does not apply. A per curiam opinion with concurrences from all seven justices, Bottoson v. Moore $e^{109}$ points out the struggles that the states have had in coming to terms with Ring's mandate. The part of the per curiam opinion discussing Ring reads, almost in its entirety, as follows:

Although Bottoson contends that he is entitled to relief under Ring, we decline to so hold. The United States Supreme Court in February 2002 stayed Bottoson's execution and placed the present case in abeyance while it decided Ring. That Court then in June 2002 issued its decision in Ring, summarily denied Bottoson's petition for certiorari, and lifted the stay without mentioning Ring in the Bottoson order. The Court did not direct the Florida Supreme Court to reconsider Bottoson in light of Ring.

Significantly, the United States Supreme Court repeatedly has reviewed and upheld Florida's capital sentencing statute over the past quarter of a century, and although Bottoson contends that there now are areas of "irreconcilable conflict" in that precedent, the Court in Ring did not address this issue ....

cannot be so generic as to permit such disparate means as burglary or tax evasion, Schad, 501 U.S. at 633. If the Court is unwilling to accept a single crime with such generic means, the diversity of aggravating factors-pecuniary gain or future dangerousness, for example-strongly suggests that an aggravating factor must be regarded as an element that must be found beyond a reasonable doubt by a unanimous jury, Richardson v. United States, 526 U.S. 813, 820 (1999); and (3) some lower courts have suggested that double jeopardy does not prohibit one from being re-prosecuted for capital murder after a finding of insufficient evidence in the first trial when the second capital murder charge is supported by a new aggravator. Powell v. Kelly, 562 F.3d 656 (4th Cir. 2009) (conducting federal habeas review under 28 U.S.C. $\$ 2254$ ). In Powell v. Kelly, a defendant's first capital murder conviction was overturned based on a finding of insufficient evidence regarding the aggravating factor supporting the death sentence. Id. at 661 . When additional evidence was discovered that justified charging a separate aggravating factor, the defendant was re-prosecuted for capital murder based on this new aggravator. Id. This result strongly suggests that lower courts regard distinct capital aggravating facts as individual elements. Id. at 666 (accepting as reasonable the conclusion that "where there is a single murder victim accompanied by multiple" eligibility factors, double jeopardy does not bar a re-prosecution for capital murder based on a new eligibility factor); see also Blockburger v. United States, 284 U.S. 299, 304 (1932) (finding that where two statutes each contain an element that the other does not, a single act can be found to violate both statutes without violating double jeopardy). 
The Florida court thus reasons that the U.S. Supreme Court had Bottoson's claim before it at the time that it decided Ring and that the High Court's refusal to grant certiorari in Bottoson's case-even if just to vacate and remand to the Florida Court for reconsideration in light of the Ring decision-indicates the Supreme Court's belief that Florida's statute comports with the rule the Court created in Ring.

Procedural issues to one side, ${ }^{111}$ this decision raises at least as many questions as it answers. For example, the fact that the U.S. Supreme Court has repeatedly upheld the constitutionality of the Florida statute does not do the analytic work that the Florida Supreme Court seems to think that it does. Each of the decisions it cites for that proposition was decided before 2002's Ring decision, and these cases reviewed Florida's capital system exclusively on Eighth Amendment grounds. ${ }^{112}$ To cite a number of decisions, all invoking the Eighth Amendment's prohibition on cruel and unusual punishment, for the proposition that the capital statute complies with the Sixth Amendment is nothing short of perverse. What is more, the Court's brief does not actually engage the merits of whether a finding of sufficient mitigating evidence is a finding of fact giving rise to Sixth Amendment rights. ${ }^{113}$

Nonetheless, despite the dearth of analysis in the Florida court's opinion, it appears to be in line with most of the recent circuit court decisions on this issue. For example, the Tenth Circuit has concluded:

[T] he Apprendi/Ring rule should not apply here because the jury's decision that the aggravating factors outweigh the mitigating factors is not a finding of fact. Instead, it is a "highly subjective," "largely moral judgment" "regarding the punishment that a particular person deserves...." In death cases, "the sentence imposed at the penalty stage ... reflect[s] a reasoned moral response to the defendant's background, character, and crime." The Apprendi/ Ring rule applies by its terms only to findings of fact, not to moral judgments.

111 The Florida Supreme Court fails to recognize that a denial of certiorari is not a judgment on the merits and is not entitled to precedential effect. See, e.g., Teague v. Lane, 489 U.S. 288, 296 (1989) ("As we have often stated, the "denial of a writ of certiorari imports no expression of opinion upon the merits of the case." (quoting United States v. Carver, 260 U.S. 482, 490 (1923) (Holmes, J.))). The fact that the Supreme Court had stayed the case during the pendency of the Ring case only to deny certiorari after deciding it strengthens the Florida court's reasoning, but only slightly.

112 See, e.g., Hildwin v. Florida, 490 U.S. 638 (1989); Spaziano v. Florida, 468 U.S. 447 (1984); Barclay v. Florida, 463 U.S. 939 (1983); Proffitt v. Florida, 428 U.S. 242 (1976).

113 Bottoson, 833 So. 2 d at 693.

114 United States v. Barrett, 496 F.3d 1079, 1107 (10th Cir. 2007) (alterations in original) (quoting United States v. Fields, 483 F.3d 313, 346 (5th Cir.2007) (citations omitted)); see also People v. Prieto, 66 P.3d 1123, 1147 (Cal. 2003) (describing the sentencing process as 
Similar reasoning also characterizes the forceful rejection of Ring's application to balancing by the First Circuit:

This [Ring] argument founders . . . because it assumes, without the slightest support, that the weighing of aggravating and mitigating factors is a fact. This assumption is incorrect. As other courts have recognized, the requisite weighing constitutes a process, not a fact to be found. The outcome of the weighing process is not an objective truth that is susceptible to (further) proof by either party. Hence, the weighing of aggravators and mitigators does not need to be "found."

Not all of the data points in that direction, however. For example, the Nevada capital statute calls, in the event of a deadlocked jury, for a three-judge panel to make the determinations that would otherwise fall to the jury: "[ $\mathrm{t}]$ he jury may impose a sentence of death only if it finds at least one aggravating circumstance and further finds that there are no mitigating circumstances sufficient to outweigh the aggravating circumstance or circumstances found." Court held that it would violate Ring for a three-judge panel to make either of these findings in the absence of a jury.

This second finding regarding mitigating circumstances is necessary to authorize the death penalty in Nevada, and we conclude that it is in part a factual determination, not merely discretionary weighing. So even though Ring expressly abstained from ruling on any "Sixth Amendment claim with respect to mitigating circumstances," we conclude that Ring requires a jury to make this finding as well: "If a State makes an increase in a defendant's authorized punishment contingent on the finding of a fact, that fact-no matter how the State labels it—must be found by a jury beyond a reasonable doubt."

In this regard, however, Nevada remains a significant outlier.

Despite the fact that most courts that have considered the question have determined that balancing is not a fact finding subject to Ring's limitations, ${ }^{118}$ we believe that, as a categorical statement, this

"inherently moral and normative, not factual" (quoting People v. Rodriguez, 726 P.2d 113, 144 (Cal. 1986)) (internal quotation marks omitted)).

115 U.S. v. Sampson, 486 F.3d 13, 32 (1st Cir. 2007) (citations omitted) (internal quotation marks omitted).

116 Nev. Rev. StAT. ANN. § 175.554(3) (Lexis Nexis 2009) (emphasis added).

117 Johnson v. State, 59 P.3d 450, 460 (Nev. 2002) (quoting Ring v. Arizona, 536 U.S. 584, 597 n.4 (2002)).

118 Oken v. State, 835 A.2d 1105, 1151 (Md. 2003) (explaining that "the weighing process is not a fact-finding [process]"). Courts have variously expressed this stunted view of $A p$ prendi by concluding that weighing is "moral" rather than factual, Ex parte Waldrop, 859 So. 2d 1181, 1189 (Ala. 2002), "normative, not factual," Prieto, 66 P.3d at 1147 (quoting People v. Rodriguez, 726 P.2d 113, 144 (Cal. 1986)) (internal quotation marks omitted), and by referring to the weighing process as merely a forum "for the jury to give its subjective opinion as to whether the death penalty is appropriate," State v. Whitfield, 107 S.W.3d 253, 259 (Mo. 2003) (en banc) (summarizing the prosecution's argument, but ul- 
position is largely indefensible in light of the case law and scholarly literature regarding what constitutes a question of fact. ${ }^{119}$ Although the longstanding debate regarding which determinations are truly factual is beyond the scope of this paper, ${ }^{120}$ substantive criminal law's applied definition of elements-those issues that must be left to a jury and proven beyond a reasonable doubt ${ }^{121}$-is sufficiently capacious to include the balancing process as it is administered in most jurisdictions. Particularly in a weighing state-where the jury is told what factors to place on both sides of the sentencing balancecourts' unwillingness to consider balancing to be a fact finding giving rise to Ring's jury requirement seems deliberately short-sighted.

To be sure, it is possible to define fact finding in terms of a purely descriptive account of what has already happened-the "who, when, what, and where." ${ }^{122}$ Viewed in this light, the process of determining whether the facts in aggravation outweigh the facts in mitigation so as to justify a sentence of death in a particular case is an inherently nonfactual assessment. However, such an approach to the fact/law dichotomy is needlessly formalistic and correspondingly irreconcilable with the way fact finding is generally viewed in the context of criminal

timately rejecting this position). The common thread seems to be that weighing cannot be regarded as a finding of fact because it is not sufficiently rigorous or delineated.

119 To be sure, there is considerable debate about what constitutes a finding of fact as to some sort of mixed question of fact and law. But it is anything but clear that a finding as to whether aggravators outweigh mitigators is patently classifiable under one category or the other. For a discussion regarding the complexity of determining whether a particular question is one of fact, see generally Louis L. Jaffe, Judicial Review: Question of Fact, 69 HARV. L. REV. 1020 (1956).

120 There is a long line of commentary addressing this question. See, e.g., George C. Christie, Judicial Review of Findings of Fact, 87 Nw. U. L. REv. 14, 26-31 (1992); Ronald R. Hofer, Standards of Review—Looking Beyond the Labels, 74 MARQ. L. REv. 231 (1991); Jaffe, supra note 119.

121 The Court has repeatedly recognized that due process requires that "every fact necessary" for a conviction must be proven by the prosecution beyond a reasonable doubt. In re Winship, 397 U.S. 358, 363 (1970). In Apprendi, the court explicitly linked the Sixth Amendment jury right to the due process beyond a reasonable doubt right. Apprendi v. New Jersey, 530 U.S. 466, 476-78 (2000). Thus, Winship's holding regarding the burden of proof for facts necessary for conviction is imported into Apprendi's jury-right protections. As commentators have observed, the Apprendi "controversy is almost an exact reflection of [an] earlier one, with the primary differences being that the Court has replaced as its foci the proof requirement with the requirement of jury decisionmaking." Ronald J. Allen \& Ethan A. Hastert, From Winship to Apprendi to Booker: Constitutional Command or Constitutional Blunder?, 58 STAN. L. REV. 195, 199 (2005).

122 Monaghan, supra note 6, at 235; see also Townsend v. Sain, 372 U.S. 293, 309 n.6 (1963) ("By 'issues of fact' we mean to refer to what are termed basic, primary, or historical facts: facts 'in the sense of a recital of external events ....'" (quoting Brown v. Allen, 344 U.S. 443, 506 (1953) (Frankfurter, J.))). 
cases. $^{123}$ Take, for example, the crime of negligent homicide. The crime generally requires: (1) that a person died; (2) that the defendant acted negligently; and (3) that the defendant's negligent actions caused the victim's death. The first fact, that the victim died, is obviously an historical fact; it is either true or it is not. However, the second two requirements-which unquestionably constitute the sort of "facts" that must be found by the jury beyond a reasonable doubtnecessarily require the jury to make some very non-factual, subjective, even moral assessments about the defendant.

Consider, first, the question of whether an individual acted negligently. Although the negligence determination is clearly the sort of fact that must be found beyond a reasonable doubt by the trier of fact, it is a determination that is inherently amorphous, normative, and moralistic. In evaluating whether a defendant had sufficient culpability to warrant criminal punishment, the law will instruct the jury to consider, for example, whether he "should [have been] aware of a substantial and unjustifiable risk" that the prohibited harm would occur. $^{124}$ Moreover, in assessing whether the defendant's failure to perceive the risk was sufficiently culpable, the jury must assess whether the conduct was a "gross deviation from the standard of care that a reasonable person would observe in the actor's situation." ${ }^{125}$ Obviously, this inquiry into whether a deviation from the ordinary standard of care is sufficiently "gross" and the "reasonableness" of the defendant's actions are not classic, or even readily identifiable, factual questions. Such determinations bear no relation to historical or observable facts. Nonetheless, such determinations are reserved for the jury alone. ${ }^{126}$

\footnotetext{
123 It is fair to consider all "elements" of an offense as "factual." The Court requires "proof beyond a reasonable doubt of every fact necessary to constitute the crime with which he is charged." Winship, 397 U.S. at 364 (emphasis added). Commentators have observed that the practical effect of Winship is that "the prosecution must prove all of the "elements of the offense' beyond a reasonable doubt." Note, Winship on Rough Waters: The Erosion of the Reasonable Doubt Standard, 106 HARv. L. Rev. 1093, 1096 (1993) (distinguishing between elements and affirmative defenses).

124 MOdEL PENAL CODE $\$ 2.02(2)$ (d) (1985) (defining negligence).

125 Id.

126 Winship, 397 U.S. at 361; see also Monaghan, supra note 6, at 234 n.33 ("[T]hough the question of negligence may involve considerable norm elaboration, a function ordinarily performed by judges, the question has long been viewed as one for the jury."). Some have noted the confusion in treating negligence as 'factual' and argued that in reality "this task is neither factfinding nor law declaration," and thus that clarity in the law would be best served by recognizing that "the allocation of negligence questions to the jury rests on grounds of policy, not on abstract conceptions of the intrinsic nature of the question itself." Id. at 232-33 n.22.
} 
The question of whether the individual's conduct was the legal cause of another's death similarly defies tidy, factual categorization. ${ }^{127}$ Indeed, the concept of causation has been characterized as a "purely normative question" masked with the legalistic label of "proximate cause." ${ }^{128}$ Reviewing the Model Penal Code's classic formulation of causation is illustrative: a defendant is said to have caused a result if the harm is not "too remote or accidental in its occurrence to have a just bearing on the actor's liability." ${ }^{129}$ While this conclusion is explicitly moral and judgmental, no court would consider taking it from a jury; it is an element of the offense and must be found by a jury and beyond a reasonable doubt.

It seems both obvious and wholly unremarkable that if a court were to take either of these findings-negligence or causation-away from the jury and determine them as a matter of law, it would run afoul of the Due Process Clause of the Constitution. One simply cannot be said to be guilty of negligent homicide if a fact finder does not find that he was negligent. Likewise, one is not eligible for the death penalty unless a fact finder determines both that certain aggravating facts exist and that such aggravating facts outweigh any mitigating evidence introduced at sentencing. Because these are the facts that make a defendant eligible for death, Ring requires that they be found by a jury and beyond a reasonable doubt.

Examples like negligence-and other nebulous legal concepts like obscenity ${ }^{130}$-explode the notion of factual purity espoused by the lower courts that have limited jury rights in capital sentencing. There is no litmus test that recognizes all normative assessments as nonfactual-quite the contrary. And given that Ring abolished the "line Theory and the Rule of Law, 54 VAND. L. REV. 1039, 1069-70 (2001) (describing how restating negligence law could provide "clarity, certainty, and uniform application of the common law across the United States”).

128 Id. at 1053.

129 MODEL PENAL CODE $\$ \S 2.03(2)$ (b), (3) (b) (1985).

130 Well beyond the simple negligence hypothetical, other examples of normative or moral judgments that are consistently and rightly regarded as sufficiently "factual" to trigger the jury protection abound. Other examples include damage calculations, such as loss of future earnings, see Metro. Stevedore Co. v. Rambo, 515 U.S. 291, 300-01 (1995) (discussing the effect of disability on future wages); see also Shepard v. Gen. Motors Corp., 423 F.2d 406, 410 (1st Cir. 1970) (reaffirming that "where the evidence justifies an inference of loss ... the issue of damages for loss of earning capacity is for the jury"), questions as to whether one was reasonably provoked into the proverbial "heat of passion" based on "adequate" provocation, and, of course, questions regarding obscenity within a particular community, Smith v. United States, 431 U.S. 291, 292-96 (1977) (discussing at length the obscenity standard), and even questions of future dangerousness for purposes of pretrial or civil confinement. 
between the fact finding in the guilt phase and the fact finding in the sentencing phase," ${ }^{131}$ the confidence with which many lower courts have asserted that balancing does not implicate Ring is unsettling as a matter of doctrine, even if understandable as an administrative matter. $^{132}$

In short, careful definition of "fact finding" has always proven illusory. Commentators and courts have repeatedly lamented the absence of a meaningful method for distinguishing a normative or legal question from a factual one. ${ }^{133}$ Thus, the kind of conclusions required by the Florida capital statute-that aggravating factors exist or that they outweigh any mitigating evidence-simply cannot be blithely dismissed as moral or normative rather than factual.

\section{Texas}

The second example we use to illustrate the confusion surrounding Ring's application is the Texas capital sentencing system. ${ }^{134}$ In the

131 Michael Antonio Brockland, Comment, See No Evil, Hear No Evil, Speak No Evil: An Argument for a Jury Determination of the Emmund/Tison Culpability Factors in Capital Felony Murder Cases, 27 ST. Louis U. PUB. L. Rev. 235, 235 (2007).

132 Some studies suggest that juror involvement in capital sentencing is more, not less, likely to result in sentences of death. See William J. Bowers \& Benjamin D. Steiner, Death by Default: An Empirical Demonstration of False and Forced Choices in Capital Sentencing, 77 TEX. L. REV. 605, 716-17 (1999) (asserting that the pervasive misunderstanding among jurors that persons not given the death penalty will be released on parole leads to excessive application of death as punishment); Susan D. Rozelle, The Principled Executioner: Capital Juries' Bias and the Benefits of True Bifurcation, 38 ARIZ. ST. L.J. 769, 777-94 (2006) (finding evidence showing that death qualification makes juries favor the prosecution on the question of guilt). Consequently, some have proffered that lower courts will want to fortify the option of states to employ judges as the final arbiters of capital sentences. See Jill M. Cochran, Note, Courting Death: 30 Years Since Furman, Is the Death Penalty Any Less Discriminatory? Looking at the Problem of Jury Discretion in Capital Sentencing, 38 VAL. U. L. REV. 1399, 1449-50 (2004) (arguing that states should be free to choose whether a judge is best suited to determine whether the death penalty is appropriate at the penalty phase); Benjamin Cooke, Note, Ring v. Arizona: Unnecessarily Abandoning Judges Along the Winding Road of the Death Penalty, 28 U. DAYTON L. REv. 383, 383-84 (2003) (suggesting that states adopt a procedural rule granting judges some discretion in sentencing for a death penalty case).

133 Nancy J. King \& Susan R. Klein, Beyond Blakely, 16 FED. SENT'G ReP. 316, 319 (2004) (discussing whether facts pertaining to federal criminal sentencing should be viewed as "superfacts"-something in between elements and sentencing factors); see also Baumgartner v. United States, 322 U.S. 665, 671 (1944) (stating that the scope of appellate review may differ depending on the type of "fact" in controversy); Monaghan, supra note 6, at 232-33 (discussing the difficulty of characterization and its relevance in determining the appropriate scope of appellate review).

134 Between 2000 and 2009, the state of Texas has executed between seventeen and forty persons every year. Executions, TEX. DEP'T CRIM. JUST., http://www.tdcj.state.tx.us/stat /annual.htm (last visited Feb. 18, 2011). 
rush to adopt a capital sentencing regime that would comply with the mandates of the Eighth Amendment as announced in Furman, the Texas legislature adopted a provision conditioning death on a finding of future dangerousness. ${ }^{135}$ In the run-of-the-mill Texas capital case, two questions are generally put to the jury in the capital sentencing process: "whether there is a probability that the defendant would commit criminal acts of violence that would constitute a continuing threat to society?" 136 And then, if yes:

Whether, taking into consideration all of the evidence, including the circumstances of the offense, the defendant's character and background, and the personal moral culpability of the defendant, there is a sufficient mitigating circumstance or circumstances to warrant that a sentence of life imprisonment without parole rather than a death sentence be imposed. ${ }^{137}$

Texas, unlike most capital states, limits death eligibility to a single aggravating factor; the only finding that can make a defendant eligible for the death penalty is his future dangerousness.

\section{a. Eligibility for the Death Penalty Under Texas Law}

While Texas is alone in its singular focus on future dangerousness, prediction of a defendant's continuing threat to the community is a very important factor in capital sentencing nationwide. Future dangerousness is used as an eligibility or aggravating factor "in nearly every capital jurisdiction in the United States." ${ }^{138}$ Even more striking, it is estimated as "underlying" more than half of all modern executions, and as "playing some role in the rest"; indeed, federal prosecutors have been found to raise a future dangerousness claim in " $77 \%$ of federal capital prosecutions."

Although the Texas statute requires that the aggravating factor be proven beyond a reasonable doubt, the Texas Court of Criminal Appeals-in a series of unpublished opinions-has repeatedly held that

135 See Tex. Code Crim. Proc. ANn. art. § 37.071(2) (b) (1) (West 2006). In Jurek v. Texas, 428 U.S. 262, 276 (1976), the Court upheld Texas' system as complying with the requirements of the Eighth Amendment.

136 Tex. CODE CRIM. PROC. ANN. art. § 37.071(2) (b) (1) (emphasis added).

137 Id. $\$ 37.071(\mathrm{e})(1)$ (emphasis added).

138 Meghan Shapiro, An Overdose of Dangerousness: How "Future Dangerousness" Catches the Least Culpable Capital Defendants and Undermines the Rationale for the Executions It Supports, 35 AM. J. CRIM. L. 145, 146 \& n.2 (2008) ("Future dangerousness is a requisite sentencing factor in two states, an optional statutory aggravating factor in four states, and an articulated non-statutory aggravating factor in at least two dozen states and the federal system." (citations omitted)).

139 Id. at 146-47; see also id. at 192 app. B (listing the twenty-four people that the state of Virginia has executed "based on future dangerousness alone"). 
the future dangerousness allegation need not comply with Ring's mandates. $^{140}$ For example, in 2004, condemned murderer Jesus Flores argued that his indictment failed to comply with Ring because an element of his death eligibility - that he posed a continuing threat to society-was not included in the charging document. ${ }^{141}$ The court dismissed this argument summarily:

The statutory maximum punishment in a capital murder case is death. Including the issue of future dangerousness in the indictment would not allow the State to seek a more severe punishment. Accordingly, Apprendi and Ring do not apply. ${ }^{142}$

Whether or not the Constitution requires the defendant's future dangerousness to be specifically alleged in the indictment, ${ }^{143}$ the Texas court's interpretation of the capital statute is demonstrably wrong under Ring. While it is technically true that the maximum penalty for capital murder in Texas is death, it was equally true in Arizona that the maximum penalty for first degree murder was death prior to Ring. ${ }^{144}$ It does not follow, however, that the penalty of death may be imposed based solely upon a conviction of murder; rather, the Texas capital statute makes a finding of future dangerousness a prerequisite to the imposition of death, just as other states use aggravating factors to narrow the class of death-eligible persons. A future dangerousness finding is a prerequisite to the imposition of the death penalty in Texas; if this finding is a factual one, Ring requires that it be found beyond a reasonable doubt by a jury.

140 See, e.g., Garza v. State, No. AP-75217, 2008 WL 1914673, at *8 (Tex. Crim. App. Apr. 30, 2008); Cubas v. State, No. AP-74953, 2005 WL 3956312, at *7 (Tex. Crim. App. Apr. 12, 2006); Flores v. State, No. 74258, 2004 WL 3098822, at*6 (Tex. Crim. App. Oct. 20, 2004). However, as we demonstrate in the next section, the Court of Criminal Appeals has recognized in other cases that the question of future dangerousness is "legally essential to the punishment." See infra pp. 82-83 and note 153. Thus, these cases properly illustrate the court's imprecision with regard to the Sixth Amendment implications of the Texas capital statute rather than its outright rejection of those implications.

141 Flores, 2004 WL 3098822, at *6.

142 Id.; see also Cubas, 2005 WL 3956312, at *7 (reaffirming that Apprendi and Ring are inapplicable to Texas' capital scheme). The reasoning in Cubas is particularly troubling. In Cubas, the court cites exclusively to cases finding Ring inapplicable to the finding of mitigating evidence. Cubas, 2005 WL 3956312, at $* 7$. For the reasons set forth below, this conclusion as to the weighing process in Texas is implausible; but it carries no weight with regard to the determination of whether Texas' lone aggravating factor is present.

143 The indictment requirement of the Fifth Amendment has never been incorporated into the Due Process Clause of the Fourteenth Amendment. See, e.g., Hurtado v. California, 110 U.S. 516, 538 (1884). All that is required is that the charging documents satisfy the notice requirements of due process.

144 See Walton v. Arizona, 497 U.S. 639, 643-44 (1990), overruled in part by Ring v. Arizona, 536 U.S. 584 (2002). 
The future dangerousness determination turns on a jury's assessment of whether facts such as the nature of the crime, lack of remorse, mental illness, and criminal history, on balance, suggest a propensity for future violence. ${ }^{145}$ This is obviously not a finding of historical fact-it is in many ways the opposite, a prediction of the future. However, future dangerousness is no less factual than the examples of other eligibility factors discussed in the previous section, ${ }^{146}$ and in other contexts, state and federal courts have routinely regarded the question of future dangerousness as a question of fact. ${ }^{147}$ But it is important to realize that it is not on this basis that the Texas court held Ring to be inapplicable to the finding of future dangerousness. ${ }^{148}$ The court did not hold that this determination-like balancing mitigation and aggravation-is a moral judgment and not a finding of fact. Rather, the court simply and inexplicably expressed its view that future dangerousness is not a threshold question to the imposition of death. ${ }^{149}$

This conclusion reflects the hostility of lower courts to efforts to reconcile the longstanding Eighth Amendment requirements with the more recent Sixth Amendment constraints. After Furman, Texas was forced to adopt a capital sentencing regime that narrowed the class of death eligible murderers-Texas complied with this Eighth Amendment obligation by making the ultimate penalty contingent on a showing that the individual represents a "continuing threat to society." While the existence of the narrowing factor in Texas law can therefore be traced to the Eighth Amendment's requirements, the factor is not therefore immune from more recent Sixth Amendment requirements.

\footnotetext{
145 Shapiro, supra note138, at 153.

146 See supra Part III.B.1.b.

147 See 18 U.S.C. $\$ 3142$ (b) (i) (1) (requiring that a pretrial detention order include written findings of fact as to whether release conditions "will not reasonably assure the appearance of the person" or will "endanger the safety of any other person or the community" (emphasis added)); United States v. Salerno, 481 U.S. 739, 742 (1987) (noting that denial of bail based on fear of future dangerousness must be justified in written "findings of fact"); see also People v. Buerge, No. 07CA2393, 2009 WL 3764078, at *1 (Colo. Ct. App. Nov. 12, 2009) (describing the determination as to whether one is likely to commit another sexually violent crime as a "specific finding[] of fact" and thus such findings must be deferred to by an appellate court).

148 See Garza v. State, No. AP-75217, 2008 WL 1914673, at*8 (Tex. Crim. App. Apr. 30, 2008) ("Apprendi and Ring have no applicability to Article 37.071 in its current form.").

149 It is important not to make too much of this point. Texas assigns the task of finding future dangerousness to the jury. Thus, the Ring question is more theoretical with regard to the Texas statute than it was with regard to the Florida statute, which purports to give such authority to a judge rather than the jury.
} 
b. The Selection Decision Under Texas Law

The second part of the Texas statute-dealing with balancing the mitigating evidence against the case in aggravation-is much more open-ended than the selection determination in Florida. Texas is an example of a non-weighing state; the jury is not limited to balancing the found aggravating factors-or factor, in this case-against the evidence in mitigation. ${ }^{150}$ Rather, the jury is to consider all of the evidence in the case in determining whether the defendant should live or die.

The Texas Court of Criminal Appeals has concluded that this second inquiry-what it calls the mitigation special issue-is also not a fact finding that must be made by a jury under Ring. In Perry $v$. State, the court held that the death penalty becomes a permissible punishment once the aggravating factor has been found. ${ }^{151}$ The absence of factors sufficient to mitigate death, therefore, is not a fact that increases the permissible punishment, the court reasoned; rather the presence of facts in mitigation can only lower the possible punishment. $^{152}$

It is, therefore, clear that what a jury is asked to decide in the mitigation special issue is not a "[fact] legally essential to the punishment." By the time the jury reaches the mitigation special issue, the prosecution has proven all aggravating "facts legally essential to the punishment.",53

The Fifth Circuit is in accord. ${ }^{154}$

Thus, the Texas court's rejection of the application of Ring to the balancing task is on a very different basis than the Florida court's rejection of the application of Ring to its statute. The Perry court rejected Ring's applicability not because the presence of sufficient mitigation is not a factual finding, but because it is not the kind of factual finding that Ring requires a jury to make. Stated another way, whereas in Florida the weighing determination might be considered a

\footnotetext{
150 See supra Part III.A (distinguishing between weighing and non-weighing sentencing systems).

151 Perry v. State, 158 S.W.3d 438, 448 (Tex. Crim. App. 2004).

152 See id. at 446-48.

$153 I d$. at 448 (alteration in original) (citations omitted) (quoting Blakely v. Washington, 542 U.S. 296, 313 (2004)).

154 See Granados v. Quarterman, 455 F.3d 529, 536-37 (5th Cir. 2006) ("We are not persuaded that Texas violated any principle of Apprendi or Ring in the trial of this case. Specifically, it did not do so by not asking the jury to find an absence of mitigating circumstances beyond a reasonable doubt in addition to questions it required the jury to answer. Put another way, a finding of mitigating circumstances reduces a sentence from death, rather than increasing it to death." (footnote omitted)).
} 
statutory prerequisite for death eligibility, the Texas statute explicitly conditions eligibility on future dangerousness alone.

This argument makes sense so far as it goes, but it also proves too much. Apprendi was an explicit rejection of this sort of formalism, of the idea that the state, by terming a fact a sentencing factor rather than an element of the offense, could remove that fact from the jury. The Texas Court's analysis-that the presence of sufficient mitigating factors is a condition that can only lower the possible penaltyconstitutes exactly the kind of formalism that Apprendi rejected.

For as long as there has been an Apprendi right to jury adjudication, there has been concern about the ease with which a legislature could manipulate Apprendi's protections. In her Apprendi dissent, Justice O'Connor explained that the rule mandating jury fact finding was hollow insofar as a state legislature could simply restructure the statute so as to evade the new jury right.

Thus, consistent with our decision in Patterson, New Jersey could cure its sentencing scheme, and achieve virtually the same results, by drafting its weapons possession statute in the following manner: First, New Jersey could prescribe, in the weapons possession statute itself, a range of 5 to 20 years' imprisonment for one who commits that criminal offense. Second, New Jersey could provide that a defendant convicted under the statute whom a judge finds, by a preponderance of the evidence, not to have acted with a purpose to intimidate an individual on the basis of race may receive a sentence no greater than 10 years' imprisonment. ${ }^{155}$

O'Connor argued, in essence, that all of the Court's work could be undone by making facts relevant to aggravating a sentence into facts relevant to mitigating a sentence instead. Such facts, unlike facts in aggravation, need not be proved to a jury under any fair reading of Ring.

However, in oft-overlooked language from the Apprendi majority, the Court responded to Justice O'Connor's concern: “if New Jersey simply reversed the burden of the hate crime finding (effectively assuming a crime was performed with a purpose to intimidate and then requiring a defendant to prove that it was not), we would be required to question whether the revision was constitutional under this Court's prior [due process] decisions." 
as forging a marriage between the Court's longstanding due process jurisprudence-the Winship line of cases-and the newly minted $A p$ prendi jury rights. ${ }^{157}$ In other words, the jury rights established by $A p$ prendi and its progeny are not mere lessons in statutory drafting for legislatures; the Court made clear its view that any efforts to evade the jury requirement announced in Apprendi are subject to the limitations of due process. ${ }^{158}$

While the precise nature of the "constitutional limits" on a legislature's ability to redefine a particular finding as a non-element has remained uncertain, ${ }^{159}$ the impact of Apprendi on criminal statutes has clearly been profound. State courts have recognized that legislatures cannot avoid the jury right by merely shifting the burden of proving the "essential elements" of a crime onto criminal defendants. In practical terms, this has resulted in victories for defendants when legislatures have attempted to make facts such as sexual motivations, serious bodily injury, proximity to a school, use of a firearm, and racial animus, to name but a few, as mere defenses, sentencing factors, or non-elements. ${ }^{160}$ There is now broad recognition that if a crime requires a fact that serves as an essential element for the conviction, it must be tried to a jury and found beyond a reasonable doubt. ${ }^{161}$ In a nutshell, the "formalism of the Apprendi rule is not pointless." "162 The jury right cannot be evaded by simply redefining critical elements as defenses or sentencing factors, and by analogy it seems that due process imposes limitations on the ability of a state to prescribe a sentencing default in favor of death.

Consider the implications of a capital sentencing regime that fails to comply with this theory of due process. For example, imagine a capital statute that provides that that all killings are punishable by

157 Allen \& Hastert, supra note 121, at 207 ("Apprendi and its progeny have married the beyond a reasonable doubt standard with the Sixth Amendment right to trial by jury.”).

158 It should be noted upfront that in the same breath that the Court acknowledged the due process limits, it also invoked a historical distinction "between facts in aggravation of punishment and facts in mitigation." Apprendi, 530 U.S. at 490-91 n.16. The Court was referring to the distinction between affirmative defenses and facts required to prove guilt, yet the context of the comment suggests broader applicability.

159 Patterson v. New York, 432 U.S. 197, 210 (1977).

160 Nancy J. King \& Susan R. Klein, Apprendi and Plea Bargaining, 54 STAN. L. REv. 295, 305 (2001) (noting that "Apprendi is making a big difference, in ways favorable to defendants" in cases such as these).

161 See, e.g., Middleton v. McNeil, 541 U.S. 433, 437 (2004) (noting that failure to give jury instructions requiring the State to prove every element of the offense is a violation of due process); Commonwealth v. Hoffman, 266 A.2d 726, 731 (Pa. 1970) (stating it is an "unquestioned requirement that the Commonwealth establish every element of any crime beyond a reasonable doubt").

162 King \& Klein, supra note 156, at 1486. 
death but that a defendant will be spared if no aggravating factors are present or if the aggravating factors that are present are outweighed by the mitigating factors that are also present. The effect of such a statute would be to impose upon the defendant an obligation to disqualify himself from death. Such a result would appear to comply with both the Eighth Amendment-it makes meaningful distinctions between who lives and who dies-and the Sixth Amendment-the facts necessary to support a finding of death are all found by a jury rather than a judge. There are significant constitutional concerns with such an approach, however, based on the due process right, a right that has, through Apprendi, been "married" to the Sixth Amendment jury right. ${ }^{163}$ Cases like Perry show, however, that the due process concerns recognized in Apprendi, which are triggered when a state drafts its statute so as to undermine the purpose and spirit of the jury right, have gone unheeded in the capital context.

Furthermore, the Supreme Court, in one of its few post-Ring opinions confronting such an issue, upheld just this kind of burden shifting in the capital context. In Kansas $v$. Marsh ${ }^{164}$ the Court endorsed a sentencing provision that provided for the death penalty if the state proved beyond a reasonable doubt that the case in aggravation was at least as strong as the case in mitigation. Marsh argued that this standard enabled the jury to impose the death penalty in the event of "equipoise" between the factors in aggravation and mitigation and thus had the effect of diminishing the role of the mitigation and individuation as an element of capital sentencing eligibility. The Court agreed with this description of the Kansas statute, but found no constitutional violation with such a statute.

In aggregate, our precedents confer upon defendants the right to present sentencers with information relevant to the sentencing decision and oblige sentencers to consider that information in determining the appropriate sentence. The thrust of our mitigation jurisprudence ends here. "[W]e have never held that a specific method for balancing mitigating and aggravating factors in a capital sentencing proceeding is constitutionally required." Rather, this Court has held that the States enjoy a "constitutionally permissible range of discretion in imposing the death penalty."

\footnotetext{
163 Allen \& Hastert, supra note 121, at 207.

164548 U.S. 163, 173 (2006).

$165 I d$. at 175 (alteration in original) (citations omitted) (quoting Blystone v. Pennsylvania, 494 U.S. 299, 308 (1990); Franklin v. Lynaugh, 487 U.S. 164, 179 (1988)).
} 
In support of this conclusion, the Court relied on its earlier opinion in Walton, ${ }^{166}$ which, in addition to holding that the Sixth Amendment was not implicated by judge findings as to aggravating factors, held that placing the burden of proof on the defendant to show that there were sufficient facts in mitigation to justify sparing his life was not incompatible with either the Eighth Amendment or due process. ${ }^{167}$ In other words, the Court expressly relied on a pre-Ring, pre-Apprendi holding to vindicate the sort of statutory gamesmanship and formalism that seems to expressly contravene these later decisions.

Consequently, at least as it is currently understood, Ring provides very little in the way of restraint on the way states structure their capital statutes. The Court seems in Marsh to endorse, at least implicitly, statutes that would excuse the state from having to prove that the case in aggravation is stronger than the case in mitigation. Even if, as we argue, balancing is a finding of fact, Ring only applies to that finding if it increases the defendant's potential penalty. If a state can take such balancing outside of Ring's protections by fiat-by changing balancing from a hurdle for the prosecution to clear to an opportunity for the defendant to spare his life-then Ring's promise is a hollow one indeed. In sum, although the Court has married the Apprendi and Winship rights, it appears willing to ignore a key aspect of this relationship; while the Court has policed burden-shifting to the defendant in the non-capital context it has not done so with equal vigor with regard to capital sentencing.

As the next two statutes make clear, however, burden-shifting is not the only way for a state to avoid Ring's mandate. We show that states can also remove Ring from the equation by dispensing with any legalistic limits on the process of balancing, by making it look more like a moral judgment and less like a legal one.

\section{California}

California occupies an odd place in America's capital punishment regime. California has a death row population of nearly 700 people, by far the largest in the country. ${ }^{168}$ However, the state has executed

Walton v. Arizona, 497 U.S. 639, 649, 655-56 (1990), overruled on other grounds by Ring v. Arizona, 536 U.S. 584 (2002).

167 The Court intimates in Marsh that if it believed that the Kansas statute made the death penalty the "default" penalty for homicide, this would have constitutional implications. Marsh, 548 U.S. at 178-79. But it is not entirely clear why this should be true.

168 Death Row Inmates by State and Size of Death Row by Year, DeATH Penalty Info. CEnTER, http:/ / www.deathpenaltyinfo.org/death-row-inmates-state-and-size-death-row-year\#state (last visited Feb. 18, 2011) (citing Criminal Justice Project, NAACP LeGal Def. \& EduC. 
only thirteen people since Gregg was decided in $1976,{ }^{169}$ a rate of less than one execution every two years. At this rate, it would take California more than 1,400 years to execute all if its condemned inmates, even if it were to stop imposing death sentences tomorrow.

California's capital statute has caused appellate courts a fair amount of confusion over the last thirty years. ${ }^{170}$ Unlike most states, California uses special circumstances, proved at the trial stage, to determine a defendant's death eligibility. If a defendant is convicted of first degree murder and at least one special circumstance is proven to the jury, the defendant is eligible for death, and the case proceeds to a separate sentencing trial. ${ }^{171}$ At this sentencing phase, a list of factors is set forth by statute for the jury's consideration in determining whether the defendant lives or dies. The jury is not told which of these factors are aggravating and which are mitigating, nor told specifically how to balance them against one another. ${ }^{172}$ In contrast to

FUND, DEATH ROW U.S.A. (2009), available at http://www.deathpenaltyinfo.org/ documents/DRUSASummer2009.pdf); Div. of Adult Operations, Death Row Tracking System Condemned Inmate Summary List, CAL. DEP'T CORR. \& REHAB. (last visited Feb. 18, 2011),

http://www.cdcr.ca.gov/Capital_Punishment/docs/CondemnedInmateSummary.pdf.

170 See, e.g., Brown v. Sanders, 546 U.S. 212, 222-23 (2006) (disagreeing with the conclusion of the Court of Appeals that California is a weighing state and concluding the opposite).

171 The Supreme Court has endorsed this approach to death eligibility and selection against Eighth Amendment challenge. See, e.g., Tuilaepa v. California, 512 U.S. 967, 971-72 (1994) ("To render a defendant eligible for the death penalty in a homicide case, we have indicated that the trier of fact must convict the defendant of murder and find one 'aggravating circumstance' (or its equivalent) at either the guilt or penalty phase.").

172 See CAL. PENAL CODE $\$ 190.3$ (West 2009):

In determining the penalty, the trier of fact shall take into account any of the following factors if relevant:

(a) The circumstances of the crime of which the defendant was convicted in the present proceeding and the existence of any special circumstances found to be true pursuant to Section 190.1.

(b) The presence or absence of criminal activity by the defendant which involved the use or attempted use of force or violence or the express or implied threat to use force or violence.

(c) The presence or absence of any prior felony conviction.

(d) Whether or not the offense was committed while the defendant was under the influence of extreme mental or emotional disturbance.

(e) Whether or not the victim was a participant in the defendant's homicidal conduct or consented to the homicidal act.

(f) Whether or not the offense was committed under circumstances which the defendant reasonably believed to be a moral justification or extenuation for his conduct.

(g) Whether or not defendant acted under extreme duress or under the substantial domination of another person.

(h) Whether or not at the time of the offense the capacity of the defendant to appreciate the criminality of his conduct or to conform his conduct to the require- 
the special circumstances which require a yes or no answer, ${ }^{173}$ the sentencing factors set forth in the California capital statute are openended and at least potentially ambiguous. However, the U.S. Supreme Court has repeatedly rejected Eighth Amendment challenges to the statute; in fact, the Court has reasoned that California's openended sentencing has advantages over the use of so-called propositional or true/false factors:

In our decisions holding a death sentence unconstitutional because of a vague sentencing factor, the State had presented a specific proposition that the sentencer had to find true or false (e.g., whether the crime was especially heinous, atrocious, or cruel). We have held, under certain sentencing schemes, that a vague propositional factor used in the sentencing decision creates an unacceptable risk of randomness, the mark of the arbitrary and capricious sentencing process prohibited by Furman $v$. Georgia, 408 U.S. 238 (1972). Those concerns are mitigated when a factor does not require a yes or a no answer to a specific question, but instead only points the sentencer to a subject matter. ${ }^{17}$

Although the U.S. Supreme Court has not ruled on the Sixth Amendment implications of California's statute, the California Supreme Court has consistently held that Ring does not apply at all in the sentencing phase of a capital trial. ${ }^{175}$ The Court has stated explicitly that the jury's decision that the case in aggravation outweighs the case in mitigation is a moral one, not a factual one. ${ }^{176}$ "Unlike the guilt determination, 'the sentencing function is inherently moral and normative, not factual' . . and, hence, not susceptible to a burden-ofproof quantification." The United States Supreme Court decisions

ments of law was impaired as a result of mental disease or defect, or the affects [sic] of intoxication.

(i) The age of the defendant at the time of the crime.

(j) Whether or not the defendant was an accomplice to the offense and his participation in the commission of the offense was relatively minor.

(k) Any other circumstance which extenuates the gravity of the crime even though it is not a legal excuse for the crime.

173 California Penal Code Section 190.2 sets forth twenty-two special circumstances including several with multiple subparts. Examples include: (1) the murder was intentional and carried out for financial gain; (3) multiple murder; (7) the victim was a peace officer; (15) the defendant killed intentionally by means of lying in wait. Id. § 190.2.

174 Tuilaepa, 512 U.S. at 974-75 (citations omitted); see also, California v. Ramos, 463 U.S. 992, 1008-09 n.22 (1983) ("[T] he fact that the jury is given no specific guidance on how the commutation factor is to figure into its determination presents no constitutional problem.”). People v. Prieto, 66 P.3d 1123, 1155 (Cal. 2003).

176 See id. Because it is the special circumstance finding, and not the finding of any aggravating factor that makes a defendant eligible for death, no aggravating factor need be found beyond a reasonable doubt. 
rendered in Ring $v$. Arizona and Apprendi $v$. New Jersey do not compel a different conclusion." ${ }^{\text {"77 }}$

The California Court is thus quite clear about how its capital statute operates. The trial stage requires findings of fact that invoke the jury right. A defendant is not death-eligible unless the jury finds the elements of first degree murder and the special circumstance allegations to have been proven beyond a reasonable doubt. By contrast, at the sentencing phase, there is simply no fact finding to be done. According to the state high court, the jury's role in capital sentencing is "moral and normative" rather than factual. While Ring obviously applies at the trial stage, ${ }^{178}$ the California Court has consistently held that it does not apply at the sentencing stage.

Although the California courts have not explained this position with great care, ${ }^{179}$ it is a difficult proposition with which to disagree. California's capital statute may contain the language of balancing the case in aggravation against the case in mitigation, but, unlike in a weighing state like Florida, it does not require any specific findings regarding either aggravating evidence or mitigating evidence. Each juror may consider different factors; different jurors may give different weight to different factors. In fact, many of the factors set forth by the statute defy the very notion of fact finding. For example, under sentencing factor (i) the jury is instructed to consider the defendant's age at the time of the offense. It is not clear whether the jury is to consider the defendant's relatively young (or old) age at the time of the offense as a factor in aggravation or in mitigation. In fact, the California court has been clear that the legislature did not mean to assign either aggravating or mitigating significance to the defendant's age, but rather to merely alert the jury to the factor for its discretionary consideration. The jury is to make of that factor, and all of the others, what it will. This kind of subjective, open-ended, unbounded decision making is different in kind and not just in degree from the decisions juries make during the guilt phase of a criminal trial.

California thus demonstrates the ease with which the ultimate question of life and death can be removed from the jury after Ring.

177 People v. Manriquez, 123 P.3d 614, 644 (Cal. 2005) (citations omitted) (quoting People v. Hawthorne, 841 P.2d 118, 142 (Cal. 1992)).

178 The California Court has held that Ring applies to the special circumstance findings, which must be proven to a jury and beyond a reasonable doubt. See, e.g., People v. Lewis, 181 P.3d 947, 1022-23 (Cal. 2008).

179 The position was stated first in the pre-Ring case People v. Hawthorne, 841 P.2d 118, 142 (Cal. 1992), modified on reh'g, 841 P.2d 118 (Cal. 1993), and has been repeated, as a mantra, in numerous decisions since then. 
Because the selection question is described by the California courts as a moral rather than a factual one, it simply falls outside of Ring's coverage. On its own terms this logic seems to us unimpeachable; the selection process in California, as described by the California courts, does not call for the finding of any facts and thus does not implicate Ring at all. While there may be Eighth Amendment problems with a sentencing regime that leaves to the sentencer's discretion the question of whether a particular fact is aggravating or mitigating of guilt, ${ }^{180}$ it would be a stretch to argue that Ring applies to such a regime.

The logical conclusion of this approach-of making the sentencing decision less legalistic and more open-ended-is Georgia's capital statute.

\section{Georgia}

Georgia's statute, which was the subject of both the Furman and Gregg decisions, is a paradigmatic example of a non-weighing statute, in which the material that can form the basis of the case in aggravation is not limited to the statutory aggravating factors. ${ }^{181}$ But more than this, Georgia's statute is remarkable for the fact that it leaves the selection decision-whether the defendant is to live or die-to the unfettered discretion of the trier of fact. While California merely provides some guideposts for the jury in making what is ultimately a moral decision regarding the defendant's sentence, in Georgia the state has consistently refused to provide the trier of fact with any guidance whatsoever. ${ }^{182}$

Zant v. Stephens ${ }^{183}$ remains the Supreme Court's definitive ruling on the constitutionality of Georgia's open-ended selection procedures. Stephens brought an Eighth Amendment challenge to the statute, claiming that its amorphous nature failed to comply with Furman's requirement that a state make meaningful distinctions between who lives and who dies. Before it could evaluate this claim, however, the U.S. Supreme Court found it necessary to certify a question to the Georgia Supreme Court, asking them to characterize the role played by aggravating factors during the selection stage of the state capital

180 And, of course, the Supreme Court has rejected those claims with regard to this statute. See e.g., Tuilaepa v. California, 512 U.S. 967, 976 (1994).

181 After Woodson v. North Carolina, 428 U.S. 280 (1976) (plurality opinion), and Lockett $v$. Ohio, 438 U.S. 586 (1978) (plurality opinion), a state cannot impose limits on what evidence may be considered in mitigation.

182 See GA. CODE ANN $\$ 17-10-31$ (2006) (laying out the findings that a jury must make to recommend the death penalty, without providing any guidelines).

183462 U.S. 862 (1983). 
punishment statute. ${ }^{184}$ The Georgia court answered that aggravating factors served no official role in sentence selection; once the state had cleared the qualification hurdle-once it had proven at least one aggravating circumstance beyond a reasonable doubt-the aggravating circumstance was afforded no statutory significance in determining the ultimate punishment. ${ }^{185}$ Rather, the question of life or death under the Georgia statute was left to the unfettered discretion of the jury. ${ }^{186}$ The Georgia court famously invoked the metaphor of a pyramid pierced by planes; each plane narrows the pool of murders until only the very top of the pyramid, those sentenced to death, remains. The Georgia court described the top of the pyramid as follows:

[A] plane separates, from all cases in which a penalty of death may be imposed, those cases in which it shall be imposed. There is an absolute discretion in the factfinder to place any given case below the plane and not impose death. The plane itself is established by the factfinder. In establishing the plane, the factfinder considers all evidence in extenuation, mitigation and aggravation of punishment. ${ }^{187}$

This sort of unbridled sentencing discretion appears to be precisely the sort of lightning-strike model of justice that was held unconstitutional in Furman. ${ }^{188}$ For the last fifty years, unchecked discretion has been equated with a level of capriciousness that is prohibited by the Eighth Amendment's ban on cruel and unusual punishment. ${ }^{189} \mathrm{Al}-$ though this statute might appear to be a clear violation of Furman's mandate of meaningful distinctions, the Zant Court held otherwise. Because rules govern the finding of aggravating factors during the earlier eligibility determination, the Court reasoned, Furman's re-

\section{(18)} provides for "categorical narrowing at the definition stage"). In other words, the Su-
preme Court determines that so long as the pool of murderers is meaningfully narrowed by a death penalty scheme, the ultimate decision may be made in an unguided way. Id. (noting that the "categorical narrowing" convinces the Court "that the structure of the statute is constitutional”).

187 Id. at 871 (quoting Zant I, 297 S.E.2d at 3-4).

188 Furman v. Georgia, 408 U.S. 238, 309-10 (1972) (Stewart, J., concurring) (criticizing the randomness in determining when the death penalty is handed out).

189 The Court's decision to uphold Georgia's sentencing scheme in Gregg effectively constitutionalized the Model Penal Code's approach to capital punishment. See supra note 57. Interestingly, the drafters of the Code have now rejected as no less arbitrary than the preFurman systems the very provision relied on by states like Georgia and endorsed by the Court. See Model Penal Code $§ 6.06$ \& cmt. b (Discussion Draft No. 2 2009). 
quirement is satisfied, and Georgia is free to structure the ultimate selection decision as it wishes. ${ }^{190}$

Stephens' challenge to the Georgia statute was an Eighth Amendment claim; at that time Zant was decided, the Supreme Court clearly believed that the Sixth Amendment did not apply in the capital sentencing context. ${ }^{191}$ However, the Ring analysis of this reading of the Georgia statute appears relatively straightforward. ${ }^{192}$ While we, in contrast to most appellate courts that have considered the issue, tend to view weighing as a factual finding subject to Ring, we have trouble doing so with regard to Georgia's non-weighing sentencing scheme. As the U.S. Supreme Court described the statute: "[i]n Georgia, unlike some other States, the jury is not instructed to give any special weight to any aggravating circumstance, to consider multiple aggravating circumstances any more significant than a single such circumstance, or to balance aggravating against mitigating circumstances pursuant to any special standard." 193 The question posed to the Georgia jury at the selection stage is a purely moral one-the jury is merely asked to determine in its discretion whether the defendant should live or die. ${ }^{194}$ Despite the use of the phrase "factfinder"

190 In this way, the Court's opinion echoes the discredited language of McGautha $v$. California, 402 U.S. 183 (1971). Decided the year before Furman, the Court endorsed the grant of limitless discretion to the jury under California's then-applicable statute:

In light of history, experience, and the present limitations of human knowledge, we find it quite impossible to say that committing to the untrammeled discretion of the jury the power to pronounce life or death in capital cases is offensive to anything in the Constitution. The States are entitled to assume that jurors confronted with the truly awesome responsibility of decreeing death for a fellow human will act with due regard for the consequences of their decision and will consider a variety of factors, many of which will have been suggested by the evidence or by the arguments of defense counsel. For a court to attempt to catalog the appropriate factors in this elusive area could inhibit rather than expand the scope of consideration, for no list of circumstances would ever be really complete. The infinite variety of cases and facets to each case would make general standards either meaningless "boiler-plate" or a statement of the obvious that no jury would need.

Id. at $207-08$.

191 See supra Part II.A.

192 See Ring v. Arizona, 536 U.S. 584, 607-09 (2002). Perhaps for this reason, there is very little decisional law in the Georgia state courts about how Ring applies to its statute.

193 Zant v. Stephens, 462 U.S. 862, 873-74 (1983).

194 There is a paradox regarding the scope of the Ring protections. As Judge Morris Hoffman and Professor Robert Weisberg have both independently concluded, the jury-right is most meaningful when the jury's discretion is least constrained. Morris B. Hoffman, Booker, Pragmatism and the Moral Jury, 13 GeO. MASON L. Rev. 455, 456, 465-77 (2005) (discussing the moral jury's role in criminal sentencing and the benefits of eliminating a mandatory sentencing scheme); Robert Weisberg, Deregulating Death, 1983 SUP. CT. REV. 305, 391 (claiming that legal formulas may "distort" the jurors' decisions); Weisberg, supra note 8, 200-01 (discussing the notion that broader crime statutes allow for "good sense in calibrating punishment"); see also Joseph L. Hoffman, Where's the Buck?-Juror Misperception of Sentencing Responsibility in Death Penalty Cases, 70 IND. L.J. 1137, 1137 (1995) 
by the Georgia Supreme Court, the Georgia statute does not contain even the pretense of factual evaluation-the jury is told neither what factors are relevant nor how to balance them against one and other. Rather, the jury is instructed, in essence, to use its moral sense to determine the appropriate sentence. Rules do not govern this process; each juror must decide for herself what punishment is appropriate using her own factors and metrics. ${ }^{195}$

This sort of moral judgment-looking at the defendant, his act, his past, and determining without guidance whether he should live or die-simply cannot colorably be deemed a fact finding. As Professor Monaghan has explained, fact finding is an inquiry into "what happened" such that factual findings "respond to inquiries about who, when, what, and where." 196 Obviously, the jury's unfettered decision as to life or death bears none of these hallmarks of fact finding. There is no sense that the jury's task is to arrive at a "correct" judgment; if the trial court cannot explain to the jury what its task is, it is hard to see how an appellate court could find the result incorrect. ${ }^{197}$ While we have great concerns about the kind of decisions produced by such discretion-we believe, in short, that Zant was wrongly decided and that the Georgia statute violates the Eighth Amendment-

(relying on Weisberg's research to conclude that the "mystifying language of legal formality" may allow a juror to believe that he or she is not morally responsible for a capital sentencing decision (quoting Weisberg, Deregulating Death, supra, at 392) (internal quotation marks omitted)).

195 In this way, the Georgia statute closely parallels the California statute approved by the Supreme Court in McGautha, 402 U.S. at 183, and overruled by Furman, 408 U.S. 238 (1972). In McGautha, overturned only a year later in Furman, the Supreme Court approved California's standard-less discretion statute on the basis that rules are inappropriate to govern the kind of life and death decision being made by a capital jury. The Court stated: " $\mathrm{t}] \mathrm{o}$ identify before the fact those characteristics of criminal homicides and their perpetrators which call for the death penalty, and to express these characteristics in language which can be fairly understood and applied by the sentencing authority, appear to be tasks which are beyond present human ability." Id. at 204.

196 Monaghan, supra note 6, at 235 (emphasis omitted); see also Clarence Morris, Law and Fact, 55 HARV. L. REV. 1303, 1304-06 (1942) (discussing the practical distinction between questions of law and questions of fact)

197 However, the Supreme Court was influenced, in upholding the Georgia capital scheme, by the fact that jurors' decisions were reviewed by the Georgia high court to ensure proportionality. See, e.g., Zant, 462 U.S. at 879 (taking into account that the Georgia Supreme Court had reviewed the jurors' death sentence in considering the constitutionality of the Georgia death penalty statute); Gregg v. Georgia, 428 U.S. 153, 207 (1976) (reasoning that the "review function" of the Georgia Supreme Court provides "additional assurance" that the jurors' decisions were appropriate). However, a decision that a jury's sentencing decision is disproportionate cannot necessarily be seen as a rejection of the decision that a particular jury came to. A single jury simply cannot ensure the proportionality of the sentence it imposes; such a task, of necessity, must be conducted by a legal actor with access to the facts of more than one case. 
it is difficult to arrive at that result under the language of Ring. Ring requires a jury only when the decision at issue hinges on a finding of fact that is functionally equivalent to an element. ${ }^{198}$ And the Georgia statute is quite explicit that any fact finding, any rule-boundedness occurs at the eligibility stage and not at the selection stage.

If the unfettered judgment of the trier of fact whether the defendant lives or dies were treated as an Apprendi fact, then essentially all sentencing decisions would be subject to Apprendi's requirements as well. For example, the unfettered discretion that judges have to sentence within the range permitted by statute is at least as much a factual conclusion as the decision whether a defendant should live or die under a sentencing scheme like Georgia's. And Justice Scalia-in many ways the chief architect of the Apprendi revolution ${ }^{199}$-made quite clear his view that Ring is about fact finding, not about the right to be sentenced by a jury. ${ }^{200}$ If his views express those of the majority in Ring, if Ring is truly limited to findings of fact, ${ }^{201}$ then the Sixth Amendment right simply cannot be stretched to include decisionseven capital decisions-based on standardless discretion. If this is true, then Ring's practical impact might be very modest indeed.

\section{CONCLUSION}

All of this brings us back to the start, to the question of how the Sixth and Eighth Amendments interact in the capital context. We have attempted to show, through the application of Ring to a number of representative capital statutes, that the Court's apparent watershed decision has not forced much change. State and federal courts continue to take a crabbed reading of exactly what constitutes fact finding and as a result, appellate judges are permitted to reweigh aggravating and mitigating factors, and, at least in the case of Florida, a

Ring v. Arizona, 536 U.S. 584, 609 (2002) ("Because Arizona's enumerated aggravating factors operate as 'the functional equivalent of an element of the greater offense,' the Sixth Amendment requires that they be found by a jury." (citation omitted) (quoting Apprendi v. New Jersey, 530 U.S. 466, 494 n.19 (2000))).

199 Commentators tend to substantially credit (or blame) Justice Scalia for the Apprendi revolution. Professor Frank O. Bowman has summarized Justice Scalia's role as one of seducing four other Justices to his approach of "confounding simplicities." See Frank O. Bowman, III, Debacle: How the Supreme Court Has Mangled American Sentencing Law and How It Might Yet Be Mended, 77 U. CHI. L. Rev. 367, 477 (2010).

200 Supra note 77 and accompanying text.

201 As the history set forth in Part II.B, supra, indicates, Justice Scalia is on firm ground; since its decisions in Jones and Apprendi, the Court has consistently framed the Sixth Amendment right in terms of factual findings. 


\section{judge is implicitly permitted to reject a jury's conclusion that the case in aggravation is outweighed by the case in mitigation. ${ }^{202}$}

202 The abrogation of the jury's role is certainly not limited to Florida, however. Relying on Supreme Court authority, a number of states have held that judicial reweighing on appeal-in the event, say that an aggravating factor found by the jury is invalidated-is permitted. See, e.g., Clemons v. Mississippi, 494 U.S. 738, 748-49 (1990) (holding that harmless error analysis or an independent reweighing of the aggravators and mitigators by an appellate court will cure a sentencing court's reliance on an invalid aggravator); $i d$. at 754 (observing that in some instances "peculiarities in a case make appellate reweighing or harmless-error analysis extremely speculative or impossible"); Neff v. State, 849 N.E.2d 556, 562 (Ind. 2006) (noting that sometimes it is "more efficient" for an appellate court to "reweigh the aggravators and mitigators"); Leslie v. Warden, 59 P.3d 440, 446-47 (Nev. 2002) (holding that it is appropriate to reweigh aggravators and mitigators after striking an aggravator); State v. Baston, 709 N.E.2d 128, 137 (Ohio 1999) (upholding appellate reweighing and refusing to presume that the trial court acted with bias). Clemons v. Mississippi holds that such reweighing was consistent with the Court's Sixth Amendment jurisprudence as it existed in 1990. Clemons, 494 U.S. at 745 (rejecting the argument that a "defendant's right to a jury trial would be infringed when an appellate court invalidates one of two or more aggravating circumstances found by the jury"). However, it seems beyond peradventure that such a process violates the Court's post-Ring understanding of the Sixth Amendment. As Judge Merritt has explained, "it seems very likely that Ring has overruled Clemons [because] [i]n Ring, the Court held that defendants have a Sixth Amendment right to have a jury, not a judge, find aggravating circumstances in death penalty cases [and] [i]t is hard to imagine how this principle would not also apply to the reweighing process described in Clemons." Baston v. Bagley, 420 F.3d 632, 639 n.1 (6th Cir. 2005). The effect of Ring on Clemons has been slow to percolate because the Ring rule was held to be non-retroactive, thus preventing lower courts from reaching the issue in cases on habeas review. See, e.g., Lambert v. McBride, 365 F.3d 557, 561 (7th Cir. 2004). In addition, the alternative solution proposed by Clemons for remedying sentencings premised on at least one invalid aggravator-harmless error review-might also be constitutionally dubious. Certain constitutional defects involving juries, even if the harm is more symbolic than tangible, are simply not amenable to harmless error review. Cf. Tankleff v. Senkowski, 135 F.3d 235, 248 (2d Cir. 1998) (recognizing Batson claim "is a structural error that is not subject to harmless error review"); Fred P. Cavese, Case Note, Clemons v. Mississippi-Shortcut to the Executioner?, 22 PAC. L.J. 935, 968 (1991) (concluding that it will be the rare case in which harmless error analysis of a capital sentence is appropriate, and observing that "all nine justices [in Clemons] agree[d] that a harmless error ruling in that case would have been strained"); John M.M. Greabe, Spelling Guilt out of a Record? Harmless-Error Review of Conclusive Mandatory Presumptions and Elemental Misdescriptions, 74 B.U. L. REV. 819, 822-23 (1994) (considering the history of harmless error and explaining that appellate determinations that an error was harmless represent an encroachment on the jury's authority, and recognizing the general rule that violations of fundamental, basic trial rights can never be harmless); $i d$. at 849 (discussing in a different context the fact that core jury right violations are sufficiently fundamental to be regarded as structural errors); Kendra Oyer, Comment, Classifying Constructive Amendment as Trial or Structural Error, 158 U. PA. L. REv. 609, 616 (2010) ("Classifying all weighable errors as trial errors, however, makes the category of structural errors too narrow."). But see Washington v. Recuenco, 548 U.S. 212, 222 (2006) ("Failure to submit a sentencing factor to the jury, like failure to submit an element to the jury, is not structural error."); Neder v. United States, 527 U.S. 1 (1999) (applying harmless error analysis when jury was not informed of material element). 
But more than that, what this trip through the states demonstrates is that, paradoxically, the easiest way for a state to avoid complying with Ring is to move toward Georgia-like unfettered discretion or toward a California-like system that explicitly states that the selection decision is a moral rather than a factual one. As we move along a continuum from Florida's weighing statute to Georgia's completely discretionary non-weighing statute, we move from a statute that to us obviously raises Ring concerns to one that we must admit does not. Given the apparent desire of the states to take capital decision making out of the hands of juries whenever possible ${ }^{203}$ this development creates a genuine concern that Ring will inevitably push the states to adopt the kind of unprincipled, discretionary capital system adopted in Georgia. The Court's Sixth Amendment jurisprudence, in other words, pushes the states to write statutes that push at the very edges of the Eighth Amendment's edicts.

In part, these criticisms of Ring as a force of change in American capital punishment are attributable to the Court's narrow focus on fact finding. ${ }^{204}$ Unless a sentencing decision can be described as fact finding, it simply falls outside the Apprendi-Ring purview. We are not the first, obviously, to note the narrowness of the Court's Ring mandate $;^{205}$ but our investigation of how that mandate plays out in practice demonstrates just how little force it actually exerts on the states today. Because states are free to cast the ultimate sentencing decision as a moral choice rather than a factual finding, they are essentially free to avoid Ring's requirements altogether.

203 Their desire to do so is based, in no small part, on the fact that judges, particularly politically accountable judges, are more likely to impose the death penalty than are juries. See, e.g., Harris v. Alabama, 513 U.S. 504, 521 (1995) (Stevens, J., dissenting) ("Not surprisingly, given the political pressures they face, judges are far more likely than juries to impose the death penalty. This has long been the case, and the recent experience of judicial overrides confirms it. Alabama judges have vetoed only five jury recommendations of death, but they have condemned 47 defendants whom juries would have spared." (citing Hans Zeisel, Some Data on Juror AtTitudes Toward Capital Punishment 37-50 (1968))); see also Carrie A. Dannenfelser, Burch v. State: Maintaining the Jury's Traditional Role as the Voice of the Community in Capital Punishment Cases, 60 MD. L. REv. 417, 438 (2001) (suggesting the susceptibility of judges to political pressure in support of executions); Stevenson, supra note 3, at 1141 (noting that some states switched from jury to judge sentencing based on a belief that "juries that would not impose capital punishment"); $i d$. at 1143 ("Empirical analyses of judges' behavior in the override states reveals a correlation between judges' use of the override power and the dates of judicial elections.").

204 Philip English Mackey, The Inutility of Mandatory Capital Punishment: An Historical Note, 54 B.U. L. REV. 32, 32-34 (1974).

205 See, e.g., Jeffrey Abramson, Death-Is-Different Jurisprudence and the Role of the Capital Jury, 2 OHIO ST. J. CRIM. L. 117, 155 (2004) ("Ring's reliance on the Sixth Amendment entitlement to jury fact-finding has a tired, museum-like quality to it.”). 
For those of us who believe that the jury has an important role to play in capital sentencing, then, perhaps a more robust solution lies in Justice Breyer's concurrence in Ring. For Breyer, it was the Eighth Amendment, not the Sixth, that required the presence of juries in the capital process. ${ }^{206}$ Citing two decades of the Court's cruel and unusual punishment jurisprudence, Breyer explained that only the jury could reasonably be expected to express the conscience of the community necessary for a just and equitable death sentence.

In this sense, Breyer is merely echoing opinions expressed earlier, before Ring, by one of the chief Apprendi-Ring architects, Justice Stevens. Dissenting in 1995's Harris v. Alabama, Stevens expressed his displeasure with a system that allowed a judge sitting without a jury to reject the jury's recommendation of leniency and to impose death instead of a life sentence. ${ }^{207}$ For Stevens, many of the traditional justifications for the death penalty disappear when it is contrasted with a true life sentence. The only explanation that remains viable today is retribution:

An expression of community outrage carries the legitimacy of law only if it rests on fair and careful consideration, as free as possible from passion or prejudice.... Jurors' responsibilities terminate when their case ends; they answer only to their own consciences; they rarely have any concern about possible reprisals after their work is done. More importantly, they focus their attention on a particular case involving the fate of one fellow citizen, rather than on a generalized remedy for a global category of faceless violent criminals who, in the abstract, may appear unworthy of life. A jury verdict expresses a collective judgment that we may fairly presume to reflect the considered view of the community.

There is an irony at work here. As part of its Eighth Amendment jurisprudence-a jurisprudence requiring the states to make meaningful decisions between who lives and who dies-the Supreme Court has fairly consistently trumpeted the fact-finding powers of the judge over those of the jury, not just before Ring, but since. In Proffitt v. Florida, a case still cited by the Florida Supreme Court as evidence of the continued constitutionality of the advisory jury, the Court con-

206 Stevenson, supra note 3, at 1148 (describing Justice Breyer's opinion as "a striking expansion of the Eighth Amendment analysis" that was necessary to "give full meaning to the concept of the jury as a representative of the moral values and sensibilities of the community").

207 513 U.S. 504, 518-19 (1995) (noting that a jury verdict reflects the views of the community and should be given proper deference by judges).

208 Id.; State v. Dixon, 283 So. 2d 1, 8 (Fla. 1973) ("[A] trial judge with experience in the facts of criminality possesses the requisite knowledge to balance the facts of the case against the standard criminal activity which can only be developed by involvement with the trials of numerous defendants."). 
cluded that decision making by judges was more likely to lead to consistent results than would similar decision making by juries: "judicial sentencing should lead, if anything, to even greater consistency in the imposition at the trial court level of capital punishment, since a trial judge is more experienced in sentencing than a jury, and therefore is better able to impose sentences similar to those imposed in analogous cases." ${ }^{209}$ The Court has expressed a similar ambivalence about the fact-finding capacities of juries elsewhere. For example, in Schriro v. Summerlin, ${ }^{210}$ the Supreme Court refused to give Ring retroactive effect; refused, in other words to find that jury fact finding was so necessary to the fairness of a death penalty trial that due process required its retroactive application. ${ }^{21}$ In doing so, the Court disparaged the role of juror as fact-finder: the Court found that juries were likely to be confused by trial courts' instructions, did not have the benefit of seeing multiple cases, and are not used extensively outside of the United States. ${ }^{212}$

Why then is the Court trumpeting the role of juries on the one hand-in the Sixth Amendment context-while disparaging it on the other-the Eighth Amendment context? The answer seems to be, in part, the Court's narrow reading of the text of the Sixth Amendment. The Apprendi majority believes that the Amendment compels jury fact finding whether it's a good idea or not. In rejecting Justice O'Connor's repeated protests that the Apprendi majority was leading the criminal justice system to ruin, Justice Scalia remarked that it was the Sixth Amendment, not the views of the Justices, that required fact finding. To paraphrase the Court's opinion in Mapp v. Ohio, refuting Justice Cardozo's famous phrase about a blundering constable: the defendant gets a jury, but it is the law (not common sense) that gives it to him. ${ }^{213}$

And that is true as far as it goes, but it is only goes so far. The Sixth Amendment may require just that juries make the factual findings that make one eligible for death, but it does not follow that is all that the Constitution requires. The criticisms of the jury that the Court made in Schiro are valid; ${ }^{214}$ if what we care about is accurate fact-

Proffitt v. Florida, 428 U.S. 242, 252 (1976).

524 U.S. 348 (2004).

See, e.g., Teague v. Lane, 489 U.S. 288, 310 (1989) (holding that "[u]nless they fall within an exception to the general rule, new constitutional rules of criminal procedure will not be applicable to those cases which have become final before the new rules are announced").

212 Schriro, 524 U.S. at 356.

213367 U.S. 643,659 (1961).

214 Schriro, 542 U.S. at $356-58$. 
finding, making sense of complicated legal doctrines, and consistency across cases, then the jury has trouble competing with the judge. ${ }^{215}$ The power of the jury, the comparative advantage that it has over the judge, however, is expressive. ${ }^{216}$ As one commentator has observed:

The near disappearance of jury sentencing over the last few decades has not been healthy for American democracy. Strictly speaking, the regimes that have replaced jury sentencing are not anti-democratic-they were approved and to some extent designed by legislatures. Yet an examination from the perspective of deliberative democracy shows that citizens have lost something important by abolishing sentencing juries. First, as the role of the jury has receded, in Justice Souter's words, to "low-level gatekeeping," the criminal justice system has become ever more opaque to the average citizen. [C] itizens have lost sense of the day-to-day workings of the criminal justice system. Second, the professionalization of sentencing has not lived up to its promise to make sentencing outcomes more just and publicly acceptable.

In sum, the jury, representative as it is of the people, was designed to stand and still today stands as an effective bulwark against official tyranny. ${ }^{218}$ Just as jury nullification in capital cases led to modernization of the death penalty in the nineteenth century, ${ }^{219}$ so the relative unwillingness of juries today to impose a death sentence is viewed by some as an indication of the death penalty's inevitable demise. While the Court is not wrong to require the jury to find the facts that lead to death, this Article demonstrates that that protection is insufficient to allow the jury its proper role. The Court should take up the call of

215 As one commentator has observed:

Perhaps the main criticism of sentencing juries is that their lack of experience and expertise leads them to make decisions based on a fragmented understanding of the sentencing process. Unable to situate the case before them within the larger sentencing framework, juries are said to render disparate judgments in similar cases in violation of the basic principle of equality before the law. Iontcheva, supra note 12 , at 356.

$216 I d$. at 322 ("As the nullification cases demonstrate, the jury-whether at trial or at sentencing-operated as a deeply political institution in the early republic. It played a central part in the American system of checks and balances." (footnotes omitted)).

217 Id. at 338-39; see also Stevenson, supra note 3 at 1152 ("Capital jury determinations constitute one of the essential 'workings of normal democratic processes in the laboratories of the States' that provide the basis for an 'across-the-board consensus' to inform the Supreme Court's judgments in applying the proportionality principle of the Eighth Amendment." (quoting Atkins v. Virginia, 536 U.S. 304, 326 (2002) (Rehnquist, C.J., dissenting, joined by Scalia and Thomas, J.J.) )).

218 Iontcheva, supra note 12 at 327-30 (describing the rise of determinate sentencing systems through, for example, mandatory guidelines as rendering jury sentencing largely "archaic").

219 Woodson v. North Carolina, 428 U.S. 280, 289-301 (1976) (plurality opinion) (discussing reforms that several states made in response to jurors' unfavorable reactions to mandatory death sentences). 
Justices Breyer and Stevens and hold that the Eighth Amendment requires that juries determine the ultimate sentence in a capital case. 